\title{
19. CHEMICAL VARIANCE IN DEEP OCEAN BASALTS
}

\author{
Roger Hart, Physical Research Laboratory, Ahmedabad 380009, India
}

\begin{abstract}
Multiple regression analysis was used to determine the relative importance of crystal fractionation, partial melting, and seawater alteration on the concentrations of 28 elements in deep ocean basalt. The components $\mathrm{Al}_{2} \mathrm{O}_{3}, \mathrm{P}_{2} \mathrm{O}_{5}$, and $\mathrm{H}_{2} \mathrm{O}$ were used as independent variables to represent each of these processes, and the computerderived equations show a high level of significance for all 28 elements.

The $\mathrm{Al}_{2} \mathrm{O}_{3}$, total $\mathrm{Fe}$, and $\mathrm{TiO}_{2}$ of oceanic basalt vary greatly in any given region of the oceanic crust due to small-scale crystal settling. The oceanic crust is enriched in large-ion-lithophile (LIL) elements with time by off-ridge volcanism. With the notable exception of $\mathrm{Zr}$ and $\mathrm{Hf}$, seawater alteration probably affects the concentration of LIL elements, but much less than partial melting. Seawater alteration leaches significant amounts of $\mathrm{Si}$ and $\mathrm{Ca}$ from oceanic basalt while enriching it in $\mathrm{K}, \mathrm{Li}$, and $\mathrm{B}$.
\end{abstract}

\section{INTRODUCTION}

The study of chemical variation in deep ocean basalts provides a unique opportunity to evaluate the chemical characteristics of the upper mantle and the magmatic processes which generate the oceanic crust at spreading centers. However, secondary chemical exchange between oceanic basalt and seawater produces an overprinting which obscures the primary relationships. Furthermore, off-ridge volcanism contributes a component to the oceanic crust which is unlike that formed at ridge crests. The purpose of this paper is to establish criteria which will help in distinguishing chemical relationships produced by magmatism at ridge crests from those produced as an overprint by chemical exchange with seawater and those contributed by off-ridge volcanism.

Covariant and multivariate analyses were applied to all chemical data available on basement rocks cored on the first 29 DSDP legs. The analyzed DSDP samples include, in addition to tholeiitic pillow lavas, differentiated andesitic basalts, alkali and transitional-type basalts, and basalts rich in olivine and pyroxene. Most DSDP basalts are altered to a phyllosilicate assemblage dominated by $\mathrm{K}$-rich smectite. A few samples are metamorphosed to spilite and amphibolite. Sites drilled on spreading ridges or abyssal plains encountered tholeiitic lava flows either fresh, or altered to a smectiterich assemblage. The unusual rock types and alteration assemblages were encountered mainly in regions thought to be typical sites of off-ridge volcanism such as seamounts, aseismic ridges, and plateaus.

A group of 59 DSDP samples was selected to represent oceanic crust tholeiitic flows typical of ridge flanks and abyssal regions. Hereafter, the group will be referred to as TOPS (Typical Oceanic Profile Samples).

In this work the DSDP data are considered as a whole including the TOPS group. Because of the diversity of the non-TOPS DSDP samples, they were not considered as a group; however, for the most part, such a group would represent products of off-ridge volcanism. Because of the difficulty of distinguishing sills from flows, there is no way of knowing for sure if the TOPS basalt contains samples produced by off-ridge volcanism, but an effort has been made to eliminate the most obvious cases.

The elemental abundance relations in all DSDP basement samples and TOPS group of DSDP samples have been compared to Mean Ocean Ridge Basalt (MORB). The chemical data on DSDP volcanic rocks are taken from the Initial Reports of the Deep Sea Drilling Project and was compiled by Vallier (1974). The literature sources for the ridge basalt defining MORB are given in Appendix A along with specific references on the DSDP volcanic rocks.

This paper is divided into three sections. The first section compares the chemical composition of MORB with the average chemical composition of all DSDP basement samples and TOPS group of DSDP samples. The second section presents the results of a study of covariant element abundance ratios and multiple regression analysis of all three groups of basalts undertaken to establish the relative importance of magmatic processes and seawater alteration processes in determining the concentrations of various elements in the oceanic crust. The third section reports on the variation of elemental concentrations with age of the oceanic crust and depth of drill penetration into the basement.

\section{COMPARISON OF THE AVERAGE COMPOSITION OF ALL DSDP BASEMENT SAMPLES WITH TOPS BASALT AND MORB}

The average chemical compositions of all DSDP basement samples, TOPS basalt, and MORB are given in Table 1 (major elements) and Table 2 (trace elements). 
The means and standard deviations are quite distinct in all three of these groups for a number of elements. The chemical variability is highest for all DSDP basement samples. TOPS basalts show higher variability than
MORB. The major and trace elements have been classified in Table 3 (for major elements) and Table 4 (for trace elements) according to an intergroup comparison of their means and standard deviations. Figures

TABLE 1

Comparison of the Major Element Chemistry of Mean Ocean Ridge Basalt (MORB) and Typical Oceanic Profile Samples (TOPS) with all DSDP Basement Samples

\begin{tabular}{|c|c|c|c|c|c|c|c|c|c|}
\hline & \multicolumn{3}{|c|}{$\begin{array}{l}\text { Mean Ocean Ridge Basalt } \\
\text { (MORB) }\end{array}$} & \multicolumn{3}{|c|}{$\begin{array}{l}\text { Typical Oceanic Profile Sample } \\
\text { (TOPS) }\end{array}$} & \multicolumn{3}{|c|}{ All DSDP Basement Samples } \\
\hline & Mean & $\begin{array}{l}\text { Standard } \\
\text { Deviation }\end{array}$ & $\begin{array}{l}\text { No. of } \\
\text { Samples }\end{array}$ & Mean & $\begin{array}{l}\text { Standard } \\
\text { Deviation }\end{array}$ & $\begin{array}{l}\text { No. of } \\
\text { Samples }\end{array}$ & Mean & $\begin{array}{l}\text { Standard } \\
\text { Deviation }\end{array}$ & $\begin{array}{l}\text { No. of } \\
\text { Samples }\end{array}$ \\
\hline $\mathrm{SiO}_{2}$ & 49.92 & 0.61 & 49 & 49.09 & 1.54 & 59 & 47.85 & 3.28 & 157 \\
\hline $\mathrm{Al}_{2} \mathrm{O}_{3}$ & 16.08 & 1.41 & 49 & 15.48 & 1.39 & 59 & 15.33 & 1.40 & 157 \\
\hline $\mathrm{TiO}_{2}$ & 1.46 & 0.31 & 49 & 1.55 & 0.69 & 59 & 1.67 & 0.83 & 157 \\
\hline $\begin{array}{l}\text { Total } \mathrm{Fe} \\
\text { as } \mathrm{Fe}_{2} \mathrm{O}_{3}\end{array}$ & 10.29 & 1.43 & 49 & 10.48 & 2.08 & 59 & 10.86 & 2.13 & 157 \\
\hline $\mathrm{MgO}$ & 7.75 & 0.77 & 49 & 6.72 & 1.45 & 59 & 6.57 & 1.82 & 157 \\
\hline $\mathrm{CaO}$ & 11.21 & 0.63 & 49 & 10.66 & 2.14 & 59 & 9.55 & 2.33 & 157 \\
\hline $\mathrm{Na}_{2} \mathrm{O}$ & 2.79 & 0.26 & 49 & 2.73 & 0.58 & 59 & 2.85 & 0.71 & 157 \\
\hline $\mathrm{K}_{2} \mathrm{O}$ & 0.17 & 0.06 & 49 & 0.49 & 0.68 & 59 & 0.87 & 0.92 & 157 \\
\hline $\mathrm{H}_{2} \mathrm{O}$ & 0.77 & 0.29 & 49 & 2.65 & 1.31 & 59 & 3.71 & 2.19 & 157 \\
\hline $\mathrm{MnO}$ & 0.17 & 0.03 & 45 & 0.18 & 0.06 & 45 & 0.17 & 0.06 & 98 \\
\hline $\mathrm{P}_{2} \mathrm{O}_{5}$ & 0.15 & 0.05 & 42 & 0.18 & 0.11 & 50 & 0.27 & 0.23 & 139 \\
\hline $\mathrm{Fe}_{2} \mathrm{O}_{3}$ & 1.49 & 0.50 & 42 & 3.77 & 1.81 & 42 & 4.99 & 5.53 & 128 \\
\hline $\mathrm{FeO}$ & 8.04 & 1.26 & 42 & 5.96 & 2.27 & 42 & 5.74 & 2.14 & 128 \\
\hline $\mathrm{Fe}_{2} \mathrm{O}_{3} / \mathrm{FeO}$ & 0.19 & 0.08 & 42 & 0.92 & 0.90 & 42 & 1.04 & 0.81 & 128 \\
\hline
\end{tabular}

TABLE 2

Comparison of the Minor Element Chemistry of Mean Ocean Ridge Basalts (MORB) and Typical Oceanic Profile Samples (TOPS) with all DSDP Basement Samples (in ppm)

\begin{tabular}{|c|c|c|c|c|c|c|c|c|c|}
\hline & \multicolumn{3}{|c|}{$\begin{array}{l}\text { Mean Ocean Ridge Basalt } \\
\text { (MORB) }\end{array}$} & \multicolumn{3}{|c|}{$\begin{array}{l}\text { Typical Oceanic Profile Sample } \\
\text { (TOPS) }\end{array}$} & \multicolumn{3}{|c|}{ All DSDP Basement Sample } \\
\hline & Mean & $\begin{array}{l}\text { Standard } \\
\text { Deviation }\end{array}$ & $\begin{array}{l}\text { No. of } \\
\text { Samples }\end{array}$ & Mean & $\begin{array}{l}\text { Standard } \\
\text { Deviation }\end{array}$ & $\begin{array}{l}\text { No. of } \\
\text { Samples }\end{array}$ & Mean & $\begin{array}{l}\text { Standard } \\
\text { Deviation }\end{array}$ & $\begin{array}{l}\text { No. of } \\
\text { Samples }\end{array}$ \\
\hline B & $\mathrm{ND}^{\mathrm{a}}$ & ND & ND & ND & ND & ND & 17.52 & 43.26 & 21 \\
\hline $\mathrm{Ba}$ & 25.40 & 27.02 & 20 & 63.00 & 118.06 & 35 & 126.11 & 203.32 & 81 \\
\hline $\mathrm{Cl}$ & ND & ND & ND & 87.50 & 123.26 & 6 & 377.30 & 280.29 & 23 \\
\hline Co & 43.75 & 14.62 & 16 & 46.44 & 13.10 & 9 & 49.72 & 13.87 & 40 \\
\hline $\mathrm{Cr}$ & 291.29 & 98.32 & 16 & 260.09 & 105.98 & 32 & 223.88 & 130.67 & 77 \\
\hline $\mathrm{Cu}$ & 79.80 & 29.30 & 16 & 56.19 & 32.89 & 27 & 70.78 & 50.16 & 65 \\
\hline $\mathrm{Eu}$ & 1.03 & 0.21 & 5 & 1.03 & 0.49 & 8 & 1.25 & 1.13 & 14 \\
\hline $\mathrm{Ga}$ & 23.75 & 11.56 & 16 & 25.04 & 10.47 & 24 & 26.90 & 31.87 & 58 \\
\hline Hf & ND & ND & ND & 2.63 & 1.61 & 6 & 2.44 & 1.32 & 9 \\
\hline $\mathrm{La}$ & 3.02 & 1.01 & 6 & ND & ND & ND & 4.93 & 4.53 & 5 \\
\hline $\mathrm{Li}$ & 5.44 & 1.87 & 9 & 9.81 & 3.54 & 16 & 15.87 & 14.10 & 24 \\
\hline Mo & ND & ND & ND & 0.41 & 0.22 & 7 & 1.15 & 1.44 & 12 \\
\hline $\mathrm{Nb}$ & ND & ND & ND & 2.84 & 5.83 & 13 & 14.57 & 21.48 & 39 \\
\hline $\mathrm{Ni}$ & 123.33 & 39.95 & 21 & 128.24 & 45.68 & 25 & 107.32 & 64.48 & 63 \\
\hline $\mathrm{Rb}$ & 1.94 & 1.68 & 9 & 5.44 & 12.81 & 11 & 12.83 & 22.27 & 39 \\
\hline $\mathrm{Pb}$ & ND & ND & ND & 1.08 & 0.60 & 7 & 1.16 & 0.68 & 12 \\
\hline$S$ & ND & ND & ND & 128.31 & 230.27 & 16 & 124.62 & 180.86 & 34 \\
\hline $\mathrm{Sc}$ & 51.75 & 17.69 & 12 & 40.60 & 15.09 & 5 & 46.80 & 17.82 & 15 \\
\hline $\mathrm{Sr}$ & 121.81 & 26.06 & 21 & 445.64 & 116.70 & 33 & 264.47 & 234.41 & 89 \\
\hline Th & ND & ND & ND & 0.21 & 0.21 & 5 & 1.42 & 1.85 & 14 \\
\hline $\mathrm{U}$ & 0.28 & 0.08 & 6 & 0.35 & 0.32 & 9 & 0.42 & 0.39 & 25 \\
\hline V & 286.00 & 74.52 & 16 & 316.42 & 72.00 & 24 & 296.43 & 132.74 & 61 \\
\hline Y & 38.60 & 13.46 & 10 & 38.89 & 17.02 & 30 & 38.53 & 28.84 & 82 \\
\hline $\mathrm{Yb}$ & 3.75 & 1.55 & 12 & ND & ND & ND & 3.01 & 1.50 & 15 \\
\hline $\mathrm{Zn}$ & 91.81 & 33.13 & 16 & 101.38 & 36.34 & 16 & 97.92 & 31.33 & 28 \\
\hline $\mathrm{Zr}$ & 105.50 & 38.71 & 16 & 113.49 & 56.95 & 36 & 140.91 & 86.45 & 93 \\
\hline
\end{tabular}

${ }^{\mathrm{a}} \mathrm{ND}=$ No data available. 
TABLE 3

Classification of Major Elements According to a Comparison of Their Means and Standard Deviations in all DSDP Basement Samples Relative to MORB

\begin{tabular}{ccc}
\hline $\begin{array}{c}\text { Same Mean and } \\
\text { Standard Deviation }\end{array}$ & $\begin{array}{c}\text { Higher Mean, Larger } \\
\text { Standard Deviation }\end{array}$ & $\begin{array}{c}\text { Smaller Mean, Larger } \\
\text { Standard Deviation }\end{array}$ \\
\hline $\mathrm{Al}_{2} \mathrm{O}_{3}$ & $\mathrm{~K}_{2} \mathrm{O}$ & $\mathrm{SiO}_{2}$ \\
$\mathrm{Total} \mathrm{Fe}_{2}$ & $\mathrm{H}_{2} \mathrm{O}$ & $\mathrm{MgO}$ \\
as $\mathrm{Fe}_{2} \mathrm{O}_{3}$ & $\mathrm{TiO}_{2}$ & $\mathrm{CaO}$ \\
$\mathrm{MnO}$ & $\mathrm{Na}_{2} \mathrm{O}$ & \\
& $\mathrm{P}_{2} \mathrm{O}_{5}$ & \\
& &
\end{tabular}

1 and 2 give means and standard deviations of concentrations in all DSDP basement samples compared to TOPS basalts.

The elements $\mathrm{Al}, \mathrm{Fe}$, and $\mathrm{Mn}$ show no significant variation among all DSDP basement samples, TOPS basalt, and MORB. A slight decrease in Al and corresponding increase in $\mathrm{Fe}, \mathrm{Mn}$, in all DSDP basement samples and TOPS basalts may be indicated. All DSDP basement samples and TOPS basalts are depleted in Ni and $\mathrm{Cr}$ while enriched in $\mathrm{Co}, \mathrm{V}$, and $\mathrm{Ga}$ relative to MORB, suggesting old oceanic crust is more fractionated with respect to olivine than the crust at oceanic ridges.

All DSDP basement samples are enriched in $\mathrm{K}_{2} \mathrm{O}$, $\mathrm{Na}_{2} \mathrm{O}, \mathrm{P}_{2} \mathrm{O}_{5}$, and $\mathrm{TiO}_{2}$ as well as the LIL elements relative to MORB. Such enrichment is expected because the DSDP samples include many rocks produced by offridge volcanism supposedly involving lower degrees of partial melting than that normally operative at the ridge crest.
The TOPS basalts show LIL-element enrichment relative to MORB although to a lesser degree than all DSDP basement samples. The TOPS basalts contain only tholeiitic flows from ridge flanks or abyssal regions; therefore, the enrichment of LIL elements in TOPS basalts by off-ridge volcanism is not a foregone conclusion. In all, four explanations are possible:

1) TOPS basalts contain sills intruded off-ridge.

2) TOPS basalts have been LIL enriched by seawater alteration.

3) TOPS basalts are enriched in LIL elements relative to MORB because the ridge sources of magma has become depleted in LIL elements as a function of time.

4) TOPS basalts have been sampled in regions of LIL enrichment due to changes of ridge spreading rate, influence of mantle plume activity, or underlying mantle inhomogeneity.

An effort to evaluate these four possibilities will be made in the sections that follow. First of all, the covarieant elemental abundance relations are examined to determine which elements behave as coherent groups typical of magmatic processes at the ridge crest (as exhibited in MOR B), which behave as coherent groups uniquely in off-ridge sites, and which behave as coherent groups correlated to alteration parameters such as $\mathrm{H}_{2} \mathrm{O}$, $\mathrm{Fe}_{2} \mathrm{O}_{3} / \mathrm{FeO}$, sonic velocity, and density.

\section{ELEMENT ABUNDANCE RELATIONS}

The correlation matrices for covariant relations between site characteristics, physical properties, major elements, and minor elements are given separately in Appendix B for each of the three groups of samples, namely, all DSDP basement samples, TOPS basalt, and

$$
\begin{aligned}
& \boldsymbol{\Delta}=\text { MORB } \\
& \boldsymbol{0}=\text { TOPS } \\
& 0=\text { ALL DSDP ANALYSES }
\end{aligned}
$$
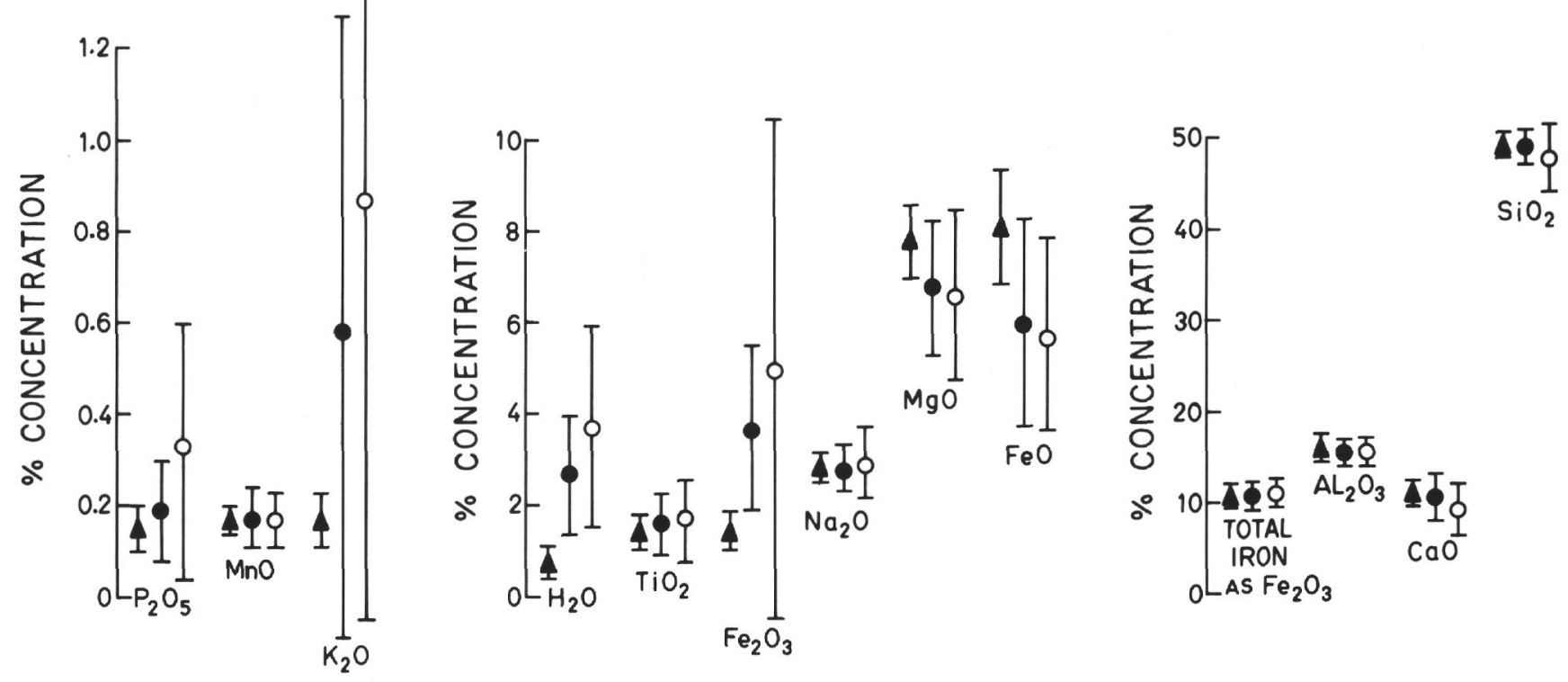

Figure 1. Means and standard deviations of major element concentrations in all DSDP basement samples (open circle) compared to TOPS basalt (closed circle) and MORB (triangle). 


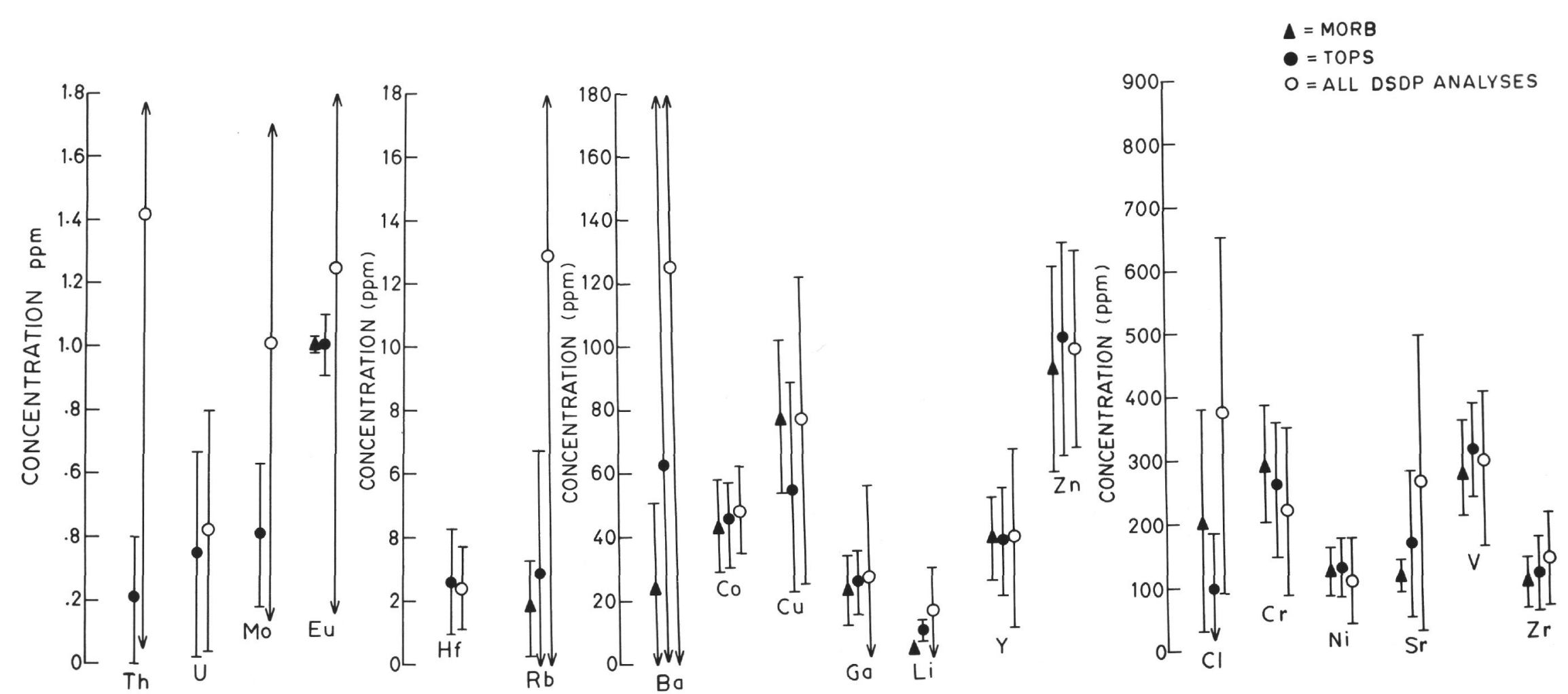

Figure 2. Means and standard deviations of trace element concentrations in all DSDP basement samples (open circle) compared to TOPS basalt (closed circle) and MORB (triangle). 
TABLE 4

Classification of Trace Elements According to Comparison

of Their Means and Standard Deviations in all DSDP Basement Samples Relative to MORB

\begin{tabular}{cccc}
\hline $\begin{array}{c}\text { Similar Mean } \\
\text { Larger Standard } \\
\text { Deviation }\end{array}$ & $\begin{array}{c}\text { Slightly Lower Mean } \\
\text { Larger Standard } \\
\text { Deviation }\end{array}$ & $\begin{array}{c}\text { Slightly Higher Mean } \\
\text { Larger Standard } \\
\text { Deviation }\end{array}$ & $\begin{array}{c}\text { Higher Mean } \\
\text { Larger Standard } \\
\text { Deviation }\end{array}$ \\
\hline $\mathrm{Y}$ & $\mathrm{Ni}$ & $\mathrm{Co}$ & $\mathrm{Th}$ \\
$\mathrm{Cu}$ & $\mathrm{Cr}$ & $\mathrm{V}$ & $\mathrm{U}$ \\
$\mathrm{Zn}$ & $\mathrm{Ga}$ & $\mathrm{Mo}$ \\
& & $\mathrm{Zr}$ & $\mathrm{Nb}$ \\
& & $\mathrm{Rb}$ \\
& & $\mathrm{Ba}$ \\
& & $\mathrm{Li}$ \\
& & $\mathrm{Cl}$ \\
& & $\mathrm{Sr}$ \\
\hline
\end{tabular}

MORB. The most significant covariant relations are discussed in this section. The major element covariant relations for all DSDP basement samples as represented diagrammatically in Figure 3 provide a good starting point for the discussion. The covariant relations showing the highest degree of correlation can be separated into three groups:

1) Those correlating with the strong negative $\mathrm{Al}_{2} \mathrm{O}_{3}$ total Fe covariance shown in Figure 4 . The group of covariant relations is thought to be produced by crystal fractionation of plagioclase relative to pyroxene. The covariance of $\mathrm{TiO}_{2}$ with total $\mathrm{Fe}$ and $\mathrm{Al}_{2} \mathrm{O}_{3}$ is shown in Figure 5.

2) Those correlating with a two to seven time enrichment of LIL elements in all DSDP basement samples relative to MORB. This group is believed to have produced by small degrees of partial melting of late magmatic phases. Covariant relations involving $\mathrm{P}_{2} \mathrm{O}_{5}$ are typical of this group. The plot of $\mathrm{P}_{2} \mathrm{O}_{5}$ versus $\mathrm{TiO}_{2}$ is shown in Figure 6. All DSDP basement samples containing greater than $0.44 \% \mathrm{P}_{2} \mathrm{O}_{3}$ have been clearly associated with sites of off-ridge volcanism in the DSDP site summaries. $\mathrm{Na}_{2} \mathrm{O}, \mathrm{MgO}$, and $\mathrm{K}_{2} \mathrm{O}$ also correlate with the group as do the LIL elements $\mathrm{Sr}, \mathrm{Zr}, \mathrm{Ba}$, and $\mathrm{Nb}$. Some of the best covariant relations in this group are shown in Figures 7, 8, and 9. The lack of correlation between $\mathrm{P}_{2} \mathrm{O}_{5}$ and $\mathrm{H}_{2} \mathrm{O}$, and $\mathrm{P}_{2} \mathrm{O}_{5}$ and $\mathrm{Al}_{2} \mathrm{O}_{3}$ as shown in Figure 10 suggests that seawater alteration and crystal settling of plagioclase relative to pyroxene have not played significant roles in establishing the covariant relationships of this group.

3) Those correlating with parameters of seawater alteration. $\mathrm{CaO}, \mathrm{SiO}_{2}$, and $\mathrm{K}_{2} \mathrm{O}$ show correlation with $\mathrm{H}_{2} \mathrm{O}$ and $\mathrm{Fe}_{2} \mathrm{O}_{3} / \mathrm{FeO}$ and some of the major covariant relations in this group are shown in Figures 11 and 12.

The degree to which elemental species correlate with each of these groups cannot be specified with a high degree of certainty using only covariant analysis since any given element may relate to more than one, or perhaps all three groups. For this reason a multiple regression analysis was applied to all DSDP basement samples along with the samples defining MORB.

On the basis of their lack of covariance to one another (see Figure 10), $\mathrm{Al}_{2} \mathrm{O}_{3}, \mathrm{P}_{2} \mathrm{O}_{5}$, and $\mathrm{H}_{2} \mathrm{O}$ were chosen as independent variables to represent, respectively, fractionation of plagioclase relative to pyroxene, par- tial melting of late magmatic phases, and seawater alteration. The multiple regression analysis was used to classify 28 elements according to which independent variable they each show the primary correlation. The results are given in Table 5 for those elements correlating primarily with $\mathrm{Al}_{2} \mathrm{O}_{3}$, in Table 6 for those elements correlating primarily with $\mathrm{P}_{2} \mathrm{O}_{5}$, and in Table 7 for those elements correlating primarily with $\mathrm{H}_{2} \mathrm{O}$. The equations represented in these tables show significant degrees of correlation for all 28 elements and on this basis it seems possible to ascertain much of the history of an oceanic basalt by simply measuring $\mathrm{Al}_{2} \mathrm{O}_{3}, \mathrm{P}_{2} \mathrm{O}_{5}$, and $\mathrm{H}_{2} \mathrm{O}$.

The results of the multiple regression analysis are summarized in Table 8, where the elements are classified according to primary, secondary, or lack of correlation with $\mathrm{Al}_{2} \mathrm{O}_{3}, \mathrm{P}_{2} \mathrm{O}_{5}$, and $\mathrm{H}_{2} \mathrm{O}$.

The elements which show primary correlation with $\mathrm{Al}_{2} \mathrm{O}_{3}$ are $\mathrm{Fe}, \mathrm{Ti}, \mathrm{Mn}, \mathrm{Co}, \mathrm{Sc}, \mathrm{Pb}, \mathrm{Ga}, \mathrm{Mo}$, and $\mathrm{Zn}$. The elements in this group which show no correlation with $\mathrm{H}_{2} \mathrm{O}$ are $\mathrm{Al}, \mathrm{Fe}, \mathrm{Ti}$, Sc. At any given sample location, including mid-ocean ridges, the concentration of these elements may vary considerably because of localized crystal fractionation in small magma bodies.

The elements which correlate primarily with $\mathrm{P}_{2} \mathrm{O}_{5}$ are the LIL elements $\mathrm{Zr}, \mathrm{Hf}, \mathrm{Ba}, \mathrm{Cl}, \mathrm{Sr}, \mathrm{Eu}$, Th, U, Rb, and $\mathrm{Nb}$. The major elements $\mathrm{Na}, \mathrm{K}$, and $\mathrm{Ti}$ correlate positively with $\mathrm{P}_{2} \mathrm{O}_{5}$, while $\mathrm{Mg}, \mathrm{Cr}$, and $\mathrm{Ni}$ show negative correlation. The elements in this group showing no correlation with $\mathrm{H}_{2} \mathrm{O}$ are $\mathrm{Ti}, \mathrm{Zr}$, and $\mathrm{Hf}$. All other elements in this group may be affected by seawater alteration, but the magnitude of the alteration effect is almost negligible compared to that produced by partial melting.

The elements that correlate primarily with $\mathrm{H}_{2} \mathrm{O}$ are $\mathrm{Ca}, \mathrm{Si}, \mathrm{K}, \mathrm{Li}, \mathrm{Cl}$, and $\mathrm{B}$. Small secondary correlations are shown by $\mathrm{Na}, \mathrm{Mn}, \mathrm{Ba}, \mathrm{Rb}, \mathrm{Pb}, \mathrm{Sr}, \mathrm{Mg}, \mathrm{Yb}, \mathrm{Eu}, \mathrm{Zn}$, $\mathrm{Th}, \mathrm{U}, \mathrm{Ga}, \mathrm{Nb}, \mathrm{Cr}, \mathrm{Cu}$, and $\mathrm{Nb}$. The elements showing no correlation with $\mathrm{H}_{2} \mathrm{O}$ and therefore the best indications of magmatic processes in the oceanic crust are $\mathrm{Zr}, \mathrm{Ti}, \mathrm{Co}, \mathrm{Ni}, \mathrm{V}, \mathrm{Hf}, \mathrm{Sc}, \mathrm{Al}$, and $\mathrm{Fe}$.

The general conclusion of the study of elemental abundance relations in this section is that seawater alteration has not produced the LIL enrichment of TOPS basalt. The next section examines age-dependent elemental relations in the oceanic crust. 

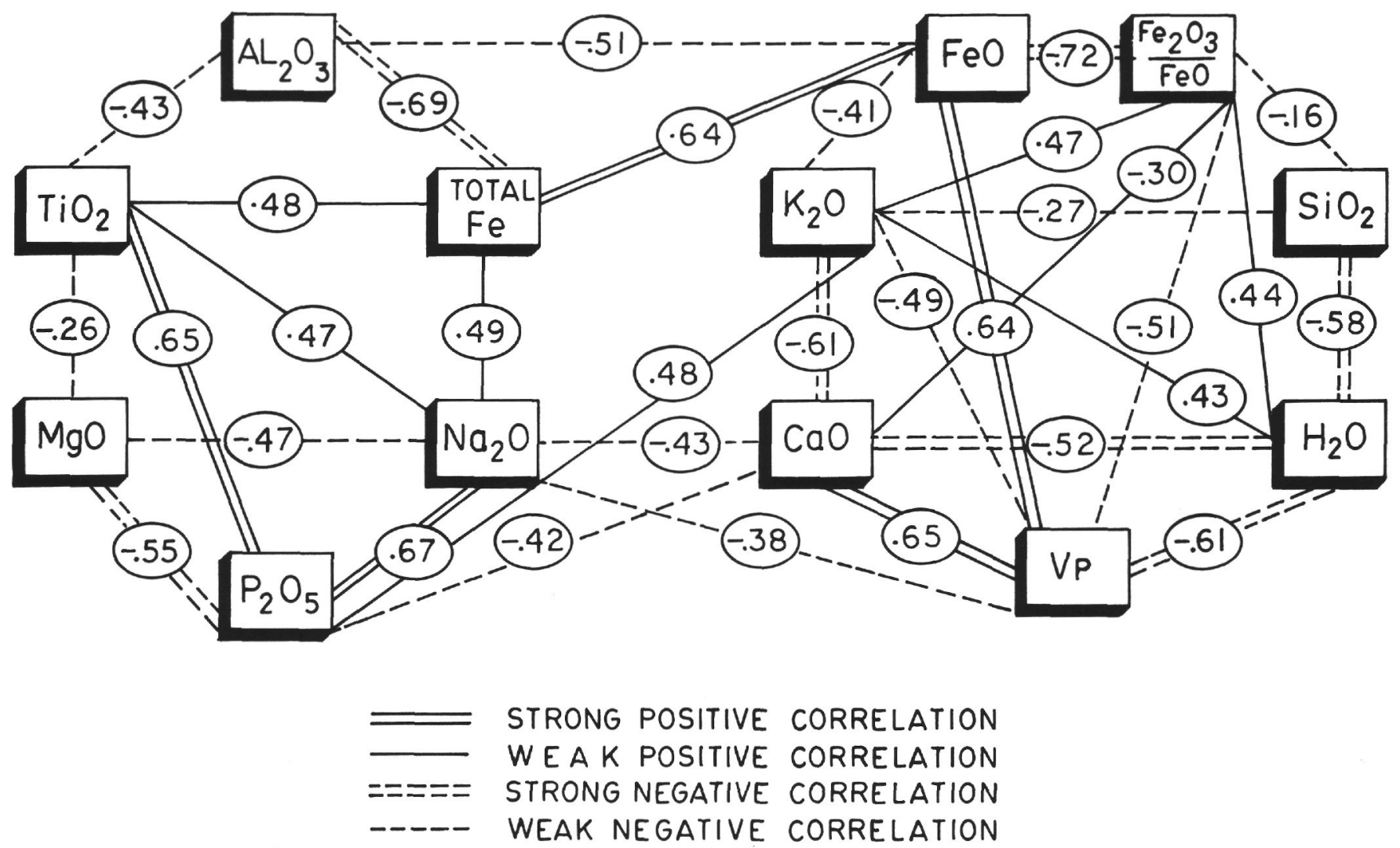

Figure 3. Diagrammatic representation of covariant major element relations in all DSDP basement samples. The numbers in circles are the correlation coefficient, $R$.

\section{DISCUSSION}

Although the average $\mathrm{Al}_{2} \mathrm{O}_{3}$ and total $\mathrm{Fe}$ concents of all DSDP basement samples are similar to MORB, basalts from about 35 DSDP sites have higher total Fe and $\mathrm{TiO}_{2}$ contents than MORB (see Figures 4 and 5). Only three DSDP basalts have lower total $\mathrm{Fe}$ and $\mathrm{TiO}_{2}$ than MORB. The majority of the high $\mathrm{Fe}$ and $\mathrm{Ti}(\mathrm{FeTi})$ DSDP basalts are rich in pyroxene, olivine, or chlorite and were sampled from sites of suspected off-ridge volcanism or mantle plume activity such as the Ninetyeast Ridge.

A significant number of TOPS basalts also show FeTi characteristics. FeTi TOPS basalts were encountered at DSDP Sites 61, 159, 160, 161, 166, 169, 172, 256, 261, 319,320 , and 321 which are removed from areas of known off-ridge volcanism or mantle plume activity. In general, the FeTi TOPS sites fall between Latitudes $10^{\circ} \mathrm{S}$ and $32^{\circ} \mathrm{N}$ in the Pacific Ocean with two sites (256 and 261 ) in the same latitude belt in the eastern Indian Ocean.

A possible explanation of FeTi TOPS basalts is that they are sills introduced near the basement-sediment contact. If this interpretation is correct then it appears that the Pacific basin may have been subjected to a higher degree of off-ridge sill intrusion than other ocean basins.

\section{CONCLUSION}

The average chemical composition of all DSDP basement sites shows an enrichment in $\mathrm{K}_{2} \mathrm{O}, \mathrm{Na}_{2} \mathrm{O}, \mathrm{P}_{2} \mathrm{O}_{5}$, and $\mathrm{TiO}_{2}$ and a depletion of $\mathrm{SiO}_{2}, \mathrm{MgO}$, and $\mathrm{CaO}$ relative to MORB. The LIL elements $\mathrm{Th}, \mathrm{U}, \mathrm{Nb}, \mathrm{Rb}$, $\mathrm{Ba}$, and $\mathrm{Sr}$ are also enriched. The average composition of a group of selected DSDP samples (TOPS) containing only tholeiitic lava flows, either fresh or altered to smectite-rich clay, and samples from only the flanks of spreading ridges or abyssal regions shows a similar but less-pronounced difference in chemical composition relative to MORB.

A multiple regression analysis of the dependency of 28 elements on the $\mathrm{Al}_{2} \mathrm{O}_{3}, \mathrm{P}_{2} \mathrm{O}_{5}$, and $\mathrm{H}_{2} \mathrm{O}$ contents of oceanic basalts shows a high degree of correlation for all elements studied and enables an evaluation of the relative importance of crystal fractionation of plagioclase relative to pyroxene, partial melting of late magmatic phases, and seawater alteration in determining the abundance of these element in oceanic basalt.

Crystal fractionation is marked by a coherent negative correlation between $\mathrm{Al}$ and $\mathrm{FeTi}$. Elements that substitute for $\mathrm{Al}$ or $\mathrm{Fe}$ such as $\mathrm{Mn}, \mathrm{Zn}, \mathrm{Sc}, \mathrm{Co}$, and $\mathrm{Ga}$ follow this trend.

Small degrees of partial melting of late magmatic stages lead to enrichment of the LIL elements. The elements $\mathrm{Ba}, \mathrm{Zr}, \mathrm{Nb}, \mathrm{U}, \mathrm{Th}, \mathrm{Hf}$, and $\mathrm{P}$ may be enriched by off-ridge volcanism two to seven times the concentrations in MORB. Crystal settling of plagioclase in magma bodies and seawater alteration affect the LIL elements to a much smaller degree than partial melting and therefore basalts with concentrations of LIL (two to 


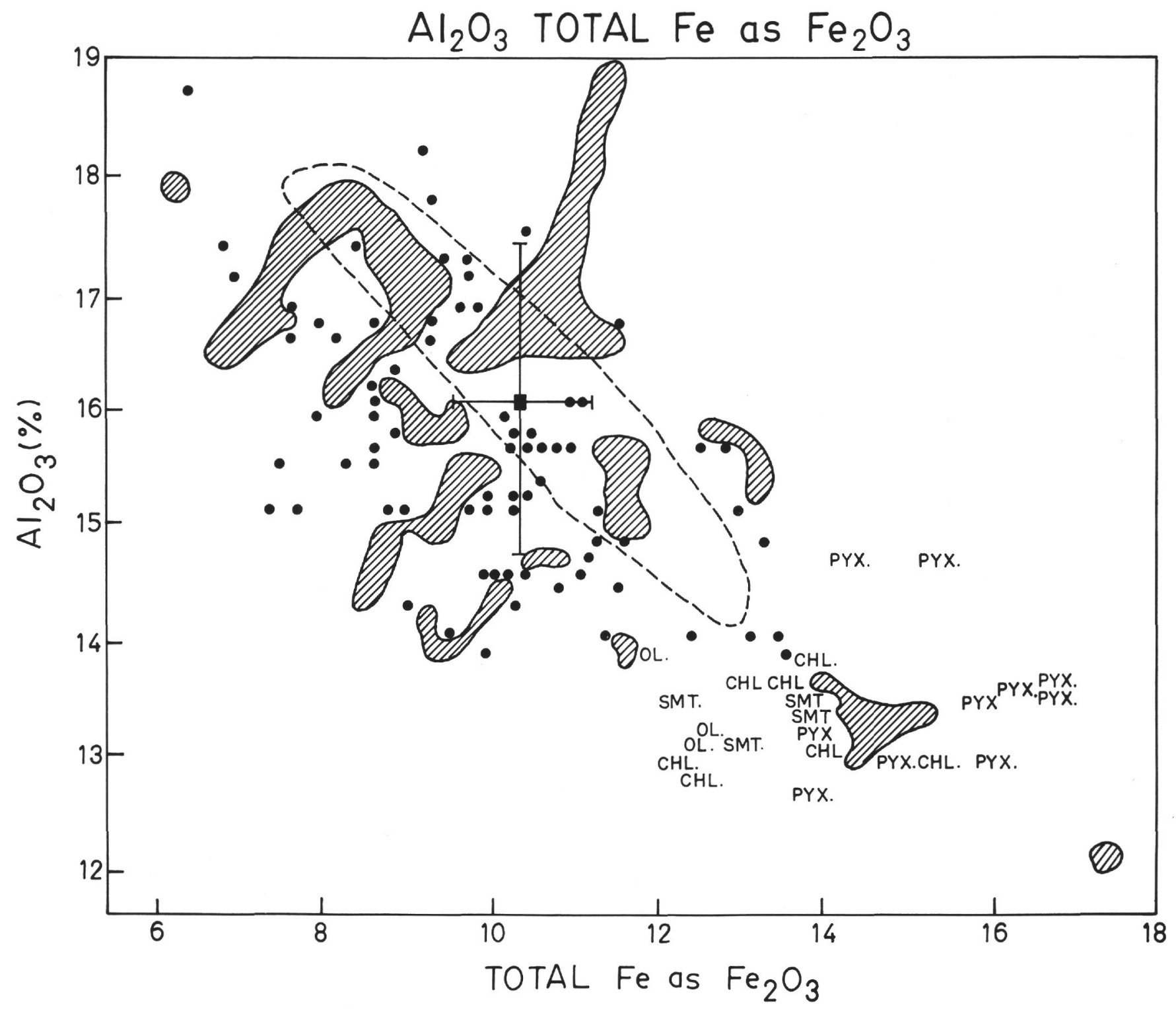

Figure 4. Plot of $\mathrm{Al}_{2} \mathrm{O}_{3}$ versus total $\mathrm{Fe}$ as $\mathrm{Fe}_{2} \mathrm{O}_{3}$ thought to have been produced by fractionation of plagioclaise relative to pyroxene. The means and standard deviations for MORB are indicated by the cross. The dashed line outlines the MORB field. The shaded areas enclose TOPS samples. The dots represent DSDP basement samples not classified as TOPS basalt. $P Y X=$ pyroxene-rich sample, $O 1=$ olivine-rich samples, $C H L=$ chlorite-rich samples, $S M T=$ alkali basalts from seamounts.

seven times that of MORB) can be safely specified as products of off-ridge volcanism. The origin of basalts with less than two times enrichment of LIL elen ints can only be judged with knowledge of $\mathrm{Al}_{2} \mathrm{O}_{3}$, and $\mathrm{H}_{2} \mathrm{O}$ contents. Seawater alteration strongly controls $\mathrm{Si}, \mathrm{Ca}, \mathrm{Li}$, $\mathrm{K}, \mathrm{Cl}$, and $\mathrm{B}$ contents of oceanic basalts.

A multiple regression analysis of the dependency of elements in TOPS basalt and MORB on the age of the oceanic crust and depth of drill penetration suggests that the abyssal portions of the oceanic crust are systematically enriched in $\mathrm{Na}_{2} \mathrm{O}, \mathrm{P}_{2} \mathrm{O}_{5}$, and $\mathrm{TiO}_{2}$ by continuous intrusion of basalt at the basement-sediment interface. Abyssal high titanium (FeTi) basalts appear to be most common in the equatorial Pacific and eastern Indian Ocean suggesting that these regions may be more subject to interplate volcanism than other oceanic regions.

\section{ACKNOWLEDGMENTS}

A critical reading by M.N. Bass inspired extensive revision of this manuscript. However, the author takes full responsibilities for the ideas presented. A grant from the Carnegie Institute of Washington made the author's participation of Leg 34 possible. The Physical Research Laboratory supported the author's shore-based computer studies. The author feels grateful to the sailors, roughnecks, and technicians aboard Glomar Challenger who made the collection of samples in this study possible.

\section{REFERENCES}

Aumento, F., 1968. The Mid-Atlantic Ridge near $45^{\circ}$ N. II: Basalts from the area of Confederation Peak: Canadian J. Earth Sci., v. 5, p. 1-21.

Bass, M.N., Moberly, R., Rhodes, J.M., Shih, C.X., and Church, S.E., 1973. Volcanic rocks cored in the Central 


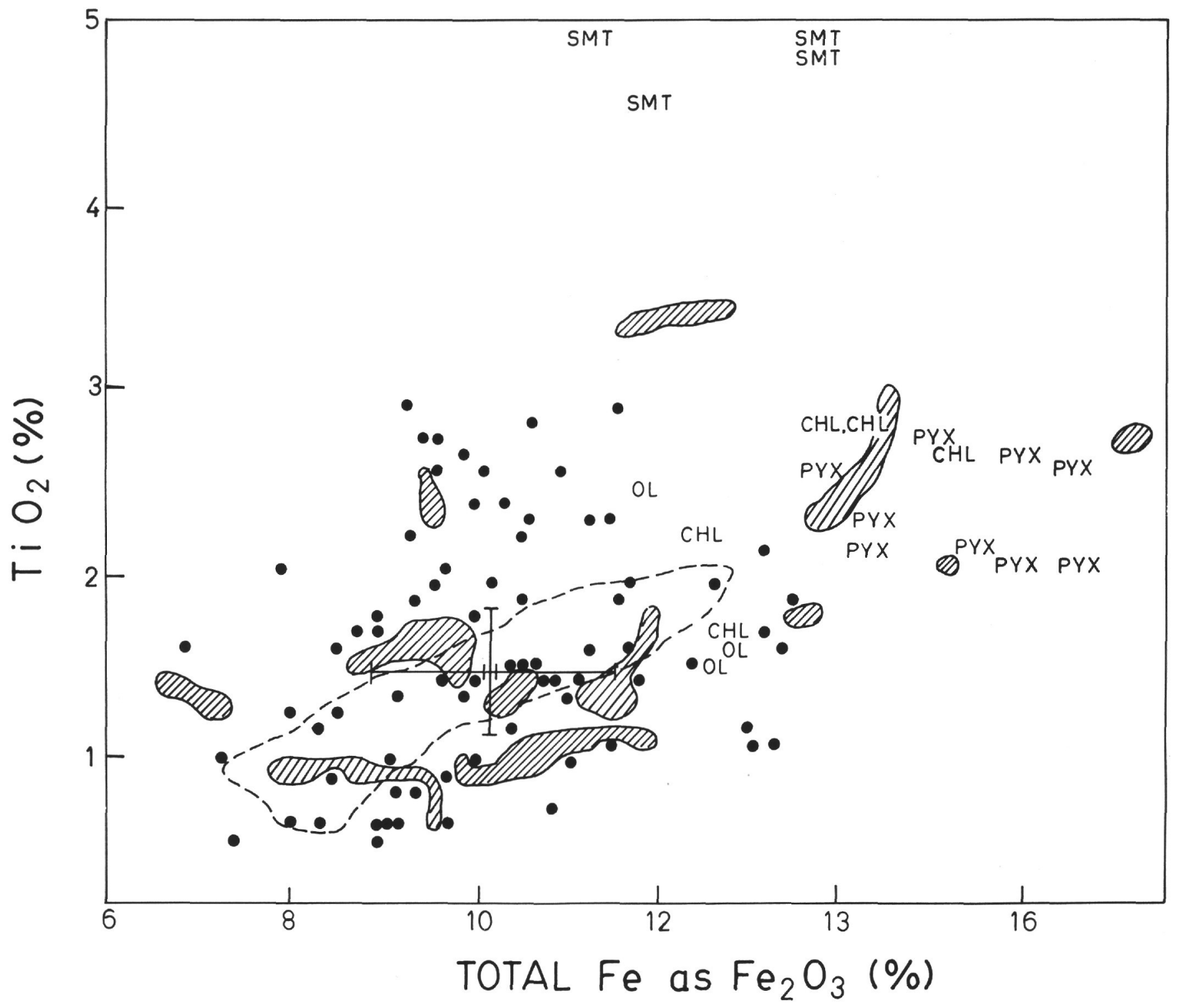

Figure 5. Covariant relations in the Al-FeTi group. The crosses represent the means and standard deviations of MORB. The dashed lines enclose the MORB field. The shaded areas enclose TOPS samples. The dots represent DSDP basement samples not classified as TOPS basalt. $P Y X=$ pyroxene-rich samples, $O L=$ olivine-rich samples, $C H L=$ chlorite-rich samples.

Pacific, Leg 17, Deep Sea Drilling Project. In Winterer, E.L., Ewing, J.I., et al., Initial Reports of the Deep Sea Drilling Project, Volume 17: Washington (U.S. Government Printing Office), p. 429-504.

Coleman, R.G., 1974. Petrology of igneous rocks in the site chapters. In Whitmarsh, R.B., Weser, O.E., Ross, D.A., et al., Initial Reports of the Deep Sea Drilling Project, Volume 23: Washington (U.S. Government Printing Office), p. 813-820.

Donnelly, T.W., Melson, W., Kay, R., and Rogers, J.J.W., 1973. Basalts and dolerites of Late Cretaceous age from the central Caribbean. In Edgar, N.T., Saunders, J.B., et al., Initial Reports of the Deep Sea Drilling Project, Volume 15: Washington (U.S. Government Printing Office), p. 9891011.

Engel, A.E.J., Engel, C.G., and Havens, R.G., 1965. Chemical characteristics of oceanic basalts and the upper mantle: Geol. Soc. Am. Bull., v. 76, p. 719-734.

Erlank, A.J. and Reid, D.L., 1974. Geochemistry, mineralogy and petrology of basalts, Leg 25, Deep Sea Drilling Project.
In Simpson, E.S.W., Schlich, R., et al., Initial Reports of the Deep Sea Drilling Project, Volume 25: Washington (U.S. Government Printing Office), p.

Hart, R.A., 1970. Chemical exchange between sea water and deep ocean basalts: Earth Planet. Sci. Lett., 9, p. 269.

Hart, S.R., Erlank, A.J., Kable, E.S.D., 1974. Sea floor basalt alteration: Some chemical and $\mathrm{Sr}$ isotopic effects: Preprint.

Hekinian, R., 1971. Chemical and mineralogical differences between abyssal hill basalts and ridge tholeiites in the eastern Pacific Ocean: Marina Geol., v. II, p. 77-91. 1973. Petrology of igneous rocks from Leg 22 in the northeastern Indian Ocean. In voh der Borch, C.C., Sclater, J.G., et al., Initial Reports of the Deep Sea Drilling Project, Volume 22: Washington (U.S. Government Printing Office), p. 413-448.

Honnorez, J. and Fox, P.J., 1973. Petrography of the Gorringe Bank "Basement". In Ryan, W.B.F., Hsü, K.J., et al., Initial Reports of the Deep Sea Drilling Project, Volume 13: Washington (U.S. Government Printing Office), p. 747749. 


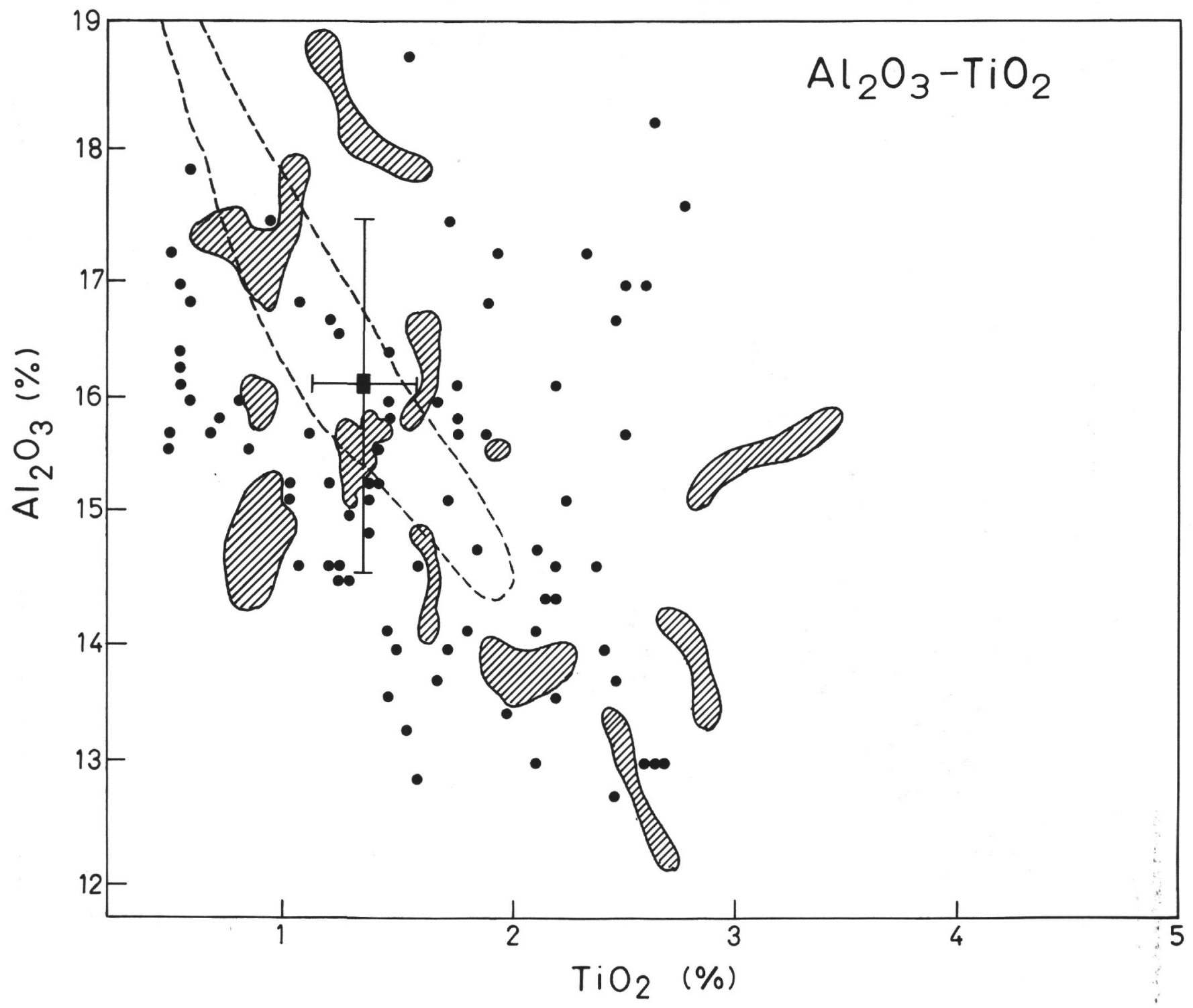

Figure 5. (Continued).

Kay, R., Hubbard, N.J., and Gast, P.W., 1970. Chemical characteristics of oceanic ridge volcanic rocks: J. Geophys. Res., v. 75, p. 1585.

Kempe, D.R.C., 1974. The Petrology of the Basalts, Leg 26. In Davies, T.A., Luyendyk, B.P., et al., Initial Reports of the Deep Sea Drilling Project, Volume, 26: Washington (U.S. Government Printing Office), p. 465-504.

McLeod, N.S. and Pratt, R.M., 1973. Petrology of volcanic rocks recovered on Leg 18. In Kulm, L.D. von Heune, R., et al., Initial Reports of the Deep Sea Drilling Project, Volume 18: Washington (U.S. Government Printing Office), p. 935-945.

Melson, W.G., Thompson, G., and Van Andel, Tj.H., 1968. Volcanism and metamorphism in the Mid-Atlantic Ridge. $22^{\circ} \mathrm{N}$ Latitude: J. Geophys. Res., v. 73, p. 5925-5941.

Miyashiro, A., Shido, F., and Ewing, M., 1969. Diversity and origin of abyssal tholeiite from the Mid-Atlantic Ridge near $24^{\circ}$ and $30^{\circ}$ north latitude: Contrib. Mineral. Petrol., v. 23 , p. 38 .

Ovenshine, A.T., Winkler, G.R., Andrews, P.B., and Gostin, V.A., 1975. Chemical analyses and minor element composi- tion of Leg 29 Basalts. In Kennett, J.P., Houtz, R.E., et ali, Initial Reports of the Deep Sea Drilling Project, Volume 29: Washington (U.S. Government Printing Office), p. 1097-1102.

Robinson, P.T. and Whitford, D.S., 1974. Basalts from the Eastern Indian Ocean DSDP Leg 27. In Veevers, J.J., Heirtzler, J.R., et al., Initial Reports of the Deep Sea Drilling Project, Volume 27: Washington (U.S. Government Printing Office), p. 551-560.

Sabine, P.A., 1972. Preliminary report on the basalt (Site 117). In Laughton, A.S., Berggren, W.A., et al., Initial Reports of the Deep Sea Drilling Project, Volume 12: Washington (U.S. Government Printing Office), p. 407-410.

Scheidegger, K.F., 1972. Temperatures and compositions of magmas ascending beneath actively spreading mid-ocean ridges: Unpublished Ph.D. Dissertation, Oregon State University, Corvallis.

Stewart, R.J., Natland, J.H., Glassley, W.R., 1973. Petrology of volcanic rocks from the North Pacific Ocean and the Bering Sea. In Creager, J.S., Scholl, D.W., et al., Initial Reports of the Deep Sea Drilling Project, Volume 19: 


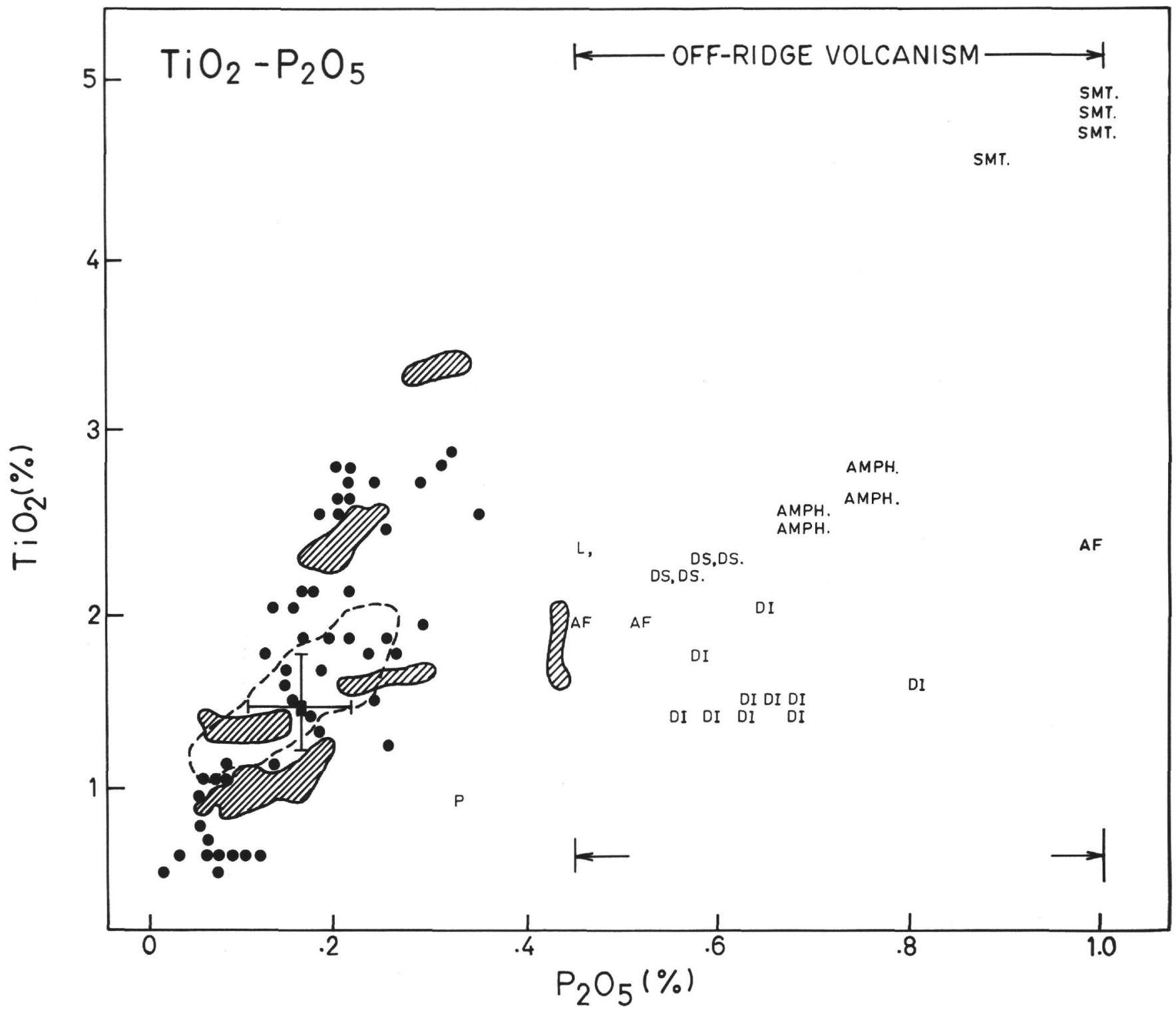

Figure 6. Plot of $\mathrm{TiO}_{2}$ versus $\mathrm{P}_{2} \mathrm{O}_{5}$. The cross represents the means and standard deviations of MORB. The dashed line outlines the MORB field. The shaded areas enclose TOPS basalt. The dots represent DSDP basement samples not classified as TOPS. $D I=$ differentiated intrusive, $D S=$ diabase sill, $A L=$ alkalic flow, $P=$ picrite, $L=$ lamprophyre, $S M T=$ alkali basalt from seamount. All samples above $44 \% \mathrm{P}_{2} \mathrm{O}_{5}$ are obvious products of magmatic differentiation at off-ridge sites.

Washington (U.S. Government Printing Office), p. 615628.

Thompson, G., Bryan, W.B., Frey, F.A., and Sung, C.M., 1973. Petrology and geochemistry of basalts and related rocks from Sites 214, 215, 216, DSDP Leg 22, Indian Ocean. In von der Borch, C.C., Sclater, J.G., et al., Initial Reports of the Deep Sea Drilling Project, Volume 22: Washington (U.S. Government Printing Office), p. 459468.

Vallier, T.L., 1974. Synthesis of chemical analyses, igneous and metamorphic rocks recovered by the Deep Sea Drilling Project: Unpublished Report, Deep Sea Drilling Project.

Weibel, M. and Hsü, K.J., 1973. Chemistry of the Valencia trough volcanic rocks. In Ryan, W.B.F., Hsü, K.J., et al.,
Initial Reports of the Deep Sea Drilling Project, Volume 13: Washington (U.S. Government Printing Office), p. 770771.

Wright, T.L., Benson, W.E., Melson, W.G., and Hart, S.R., 1972. Petrology of basaltic rocks collected from Leg 14. In Hayes, D.E., Pimm. A.C., et al., Initial Reports of the Deep Sea Drilling Project, Volume 14: Washington (U.S. Government Printing Office), p. 767-772.

Yeats, R.S., Forbes, W.C., Heath, G.R., and Scheidegger, K., 1973. Petrology and geochemistry of DSDP Leg 16 basalts, eastern equatorial Pacific. In van Andel, T.H., Heath, G.R., et al., Initial Reports of the Deep Sea Drilling Project, Volume 16: Washington (U.S. Government Printing Office), p. 617-640. 


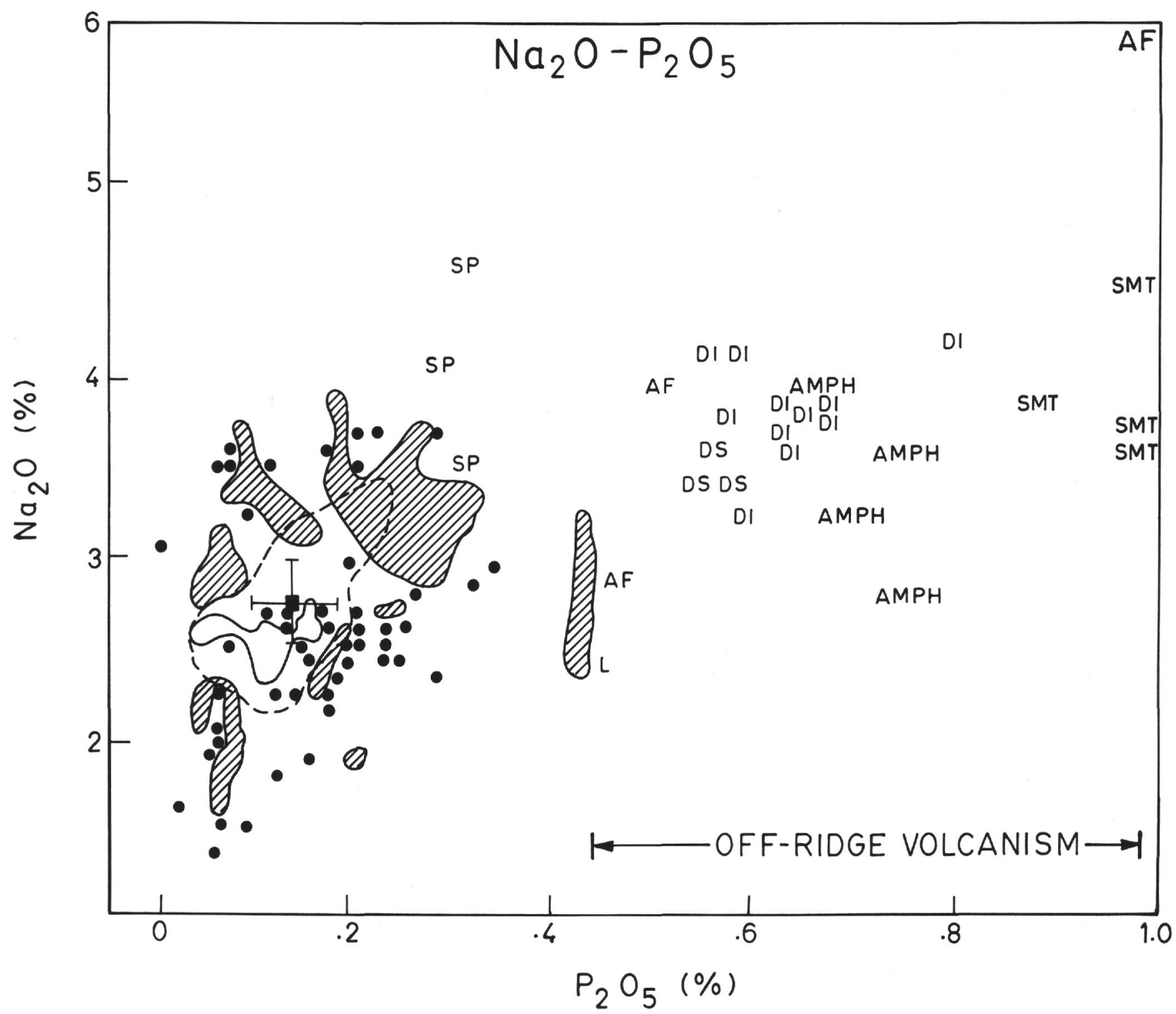

Figure 7. Covariant relations thought to be produced by partial melting of late magmatic phases. The crosses represent the means and standard deviations of MORB. The dashed line encloses the MORB field. The shaded areas enclose TOPS basalt. Circles represent DSDP basement samples not classified as TOPS basalt. DI = differentiated intrusive, DS = diabase sill, $A L=$ alkalic flow,$P=$ picrite,$L=$ lamprophyre, $S M T=$ alkali basalt from seamount,$S P=$ spilites. 


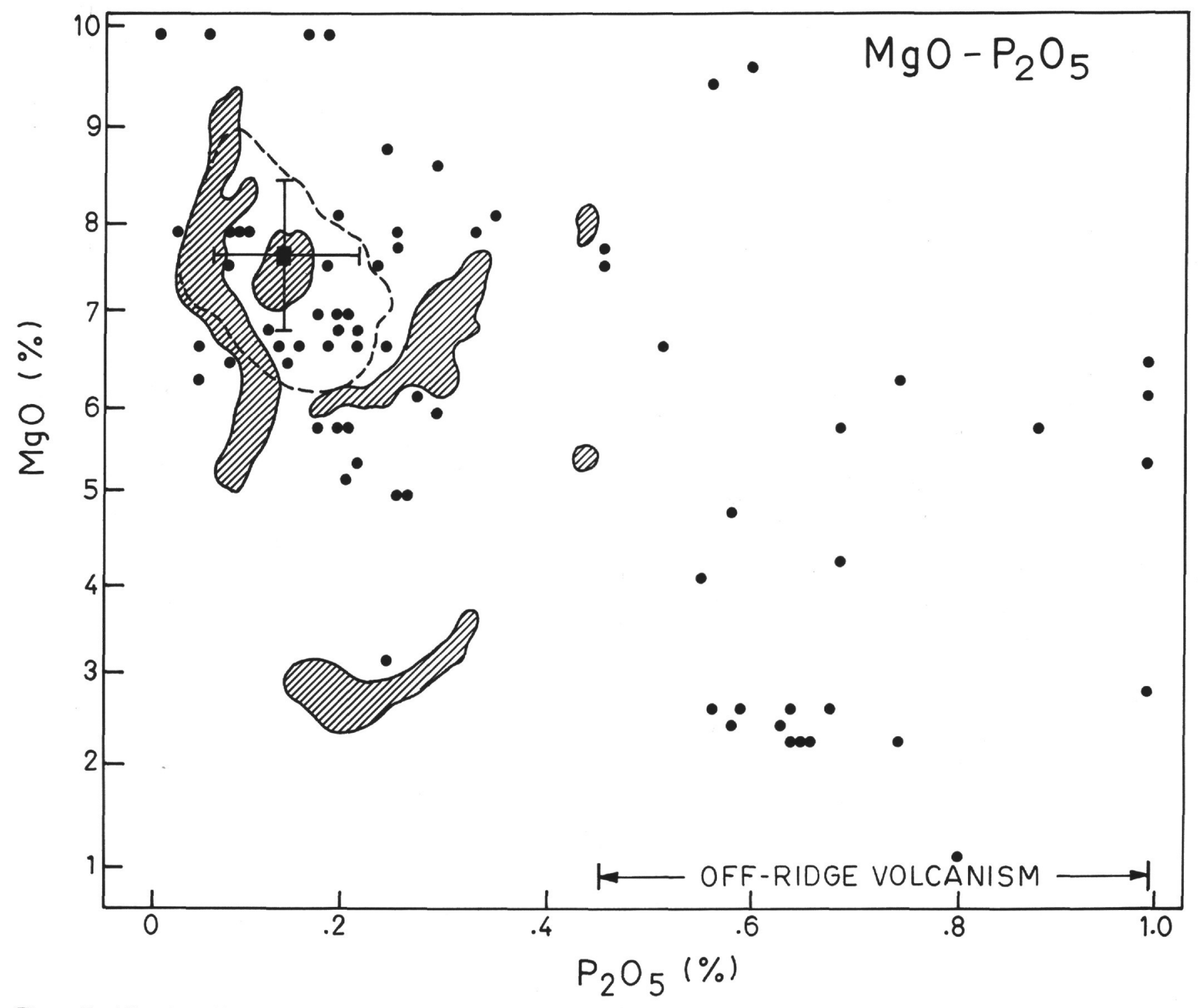

Figure 7. (Continued). 


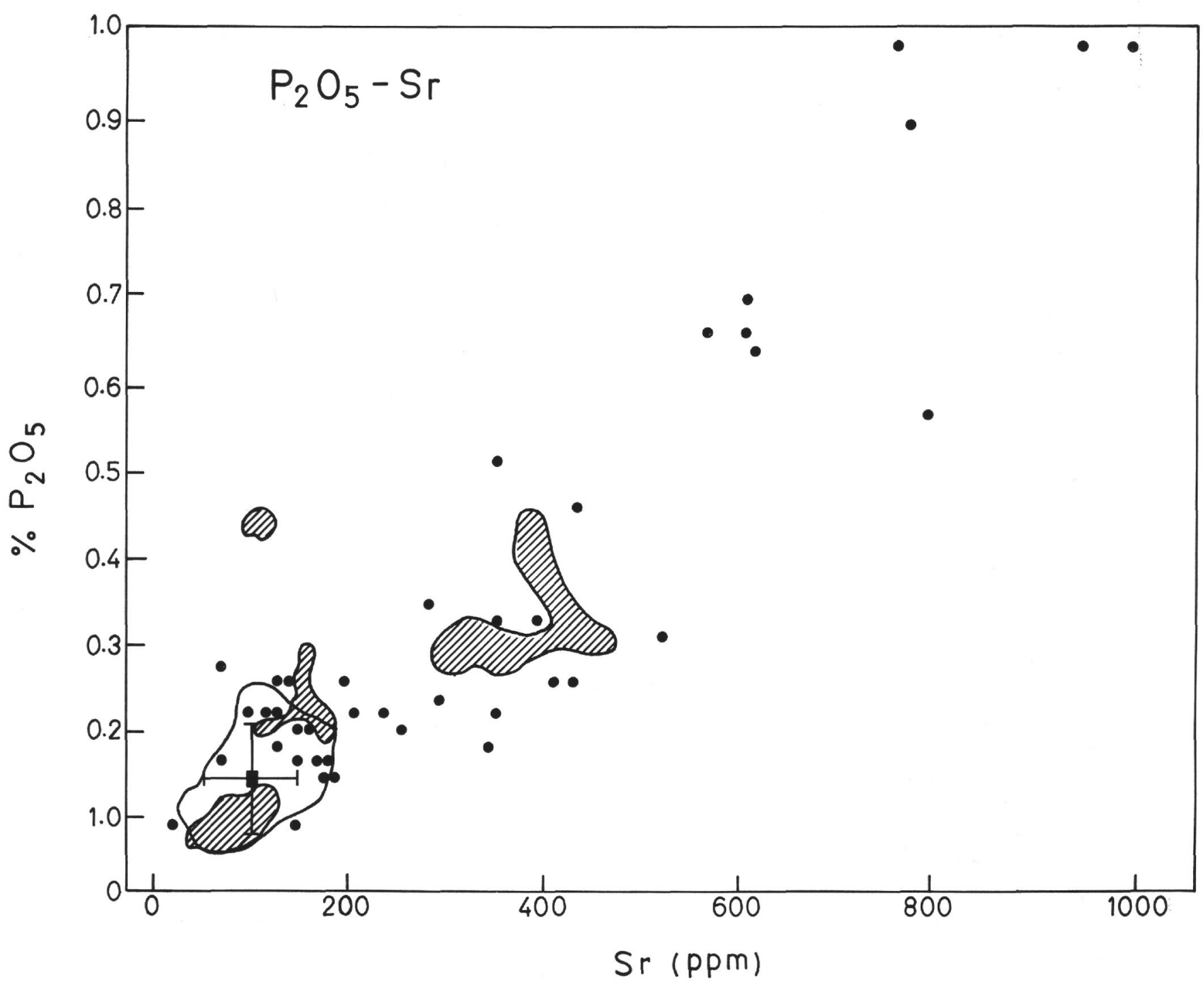

Figure 8. Covariant relations of LIL elements thought to be produced by partial melting of late magmatic phases. The crosses represents the means and standard deviations of MORB. The dashed line outlines the MORB field. Shaded areas enclose TOPS basalt. The dots represent all DSDP basement samples not classified as TOPS. 


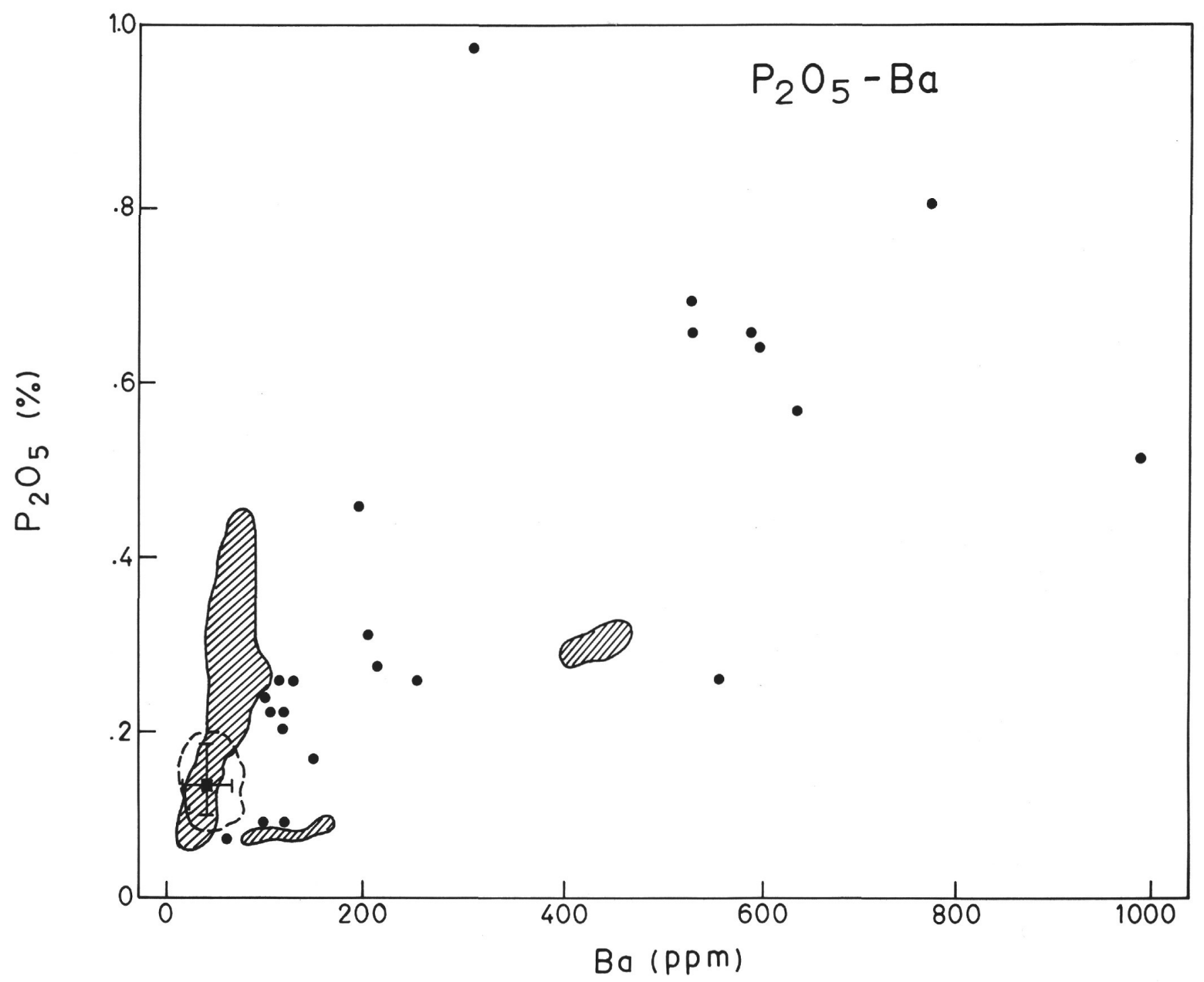

Figure 8. (Continued). 


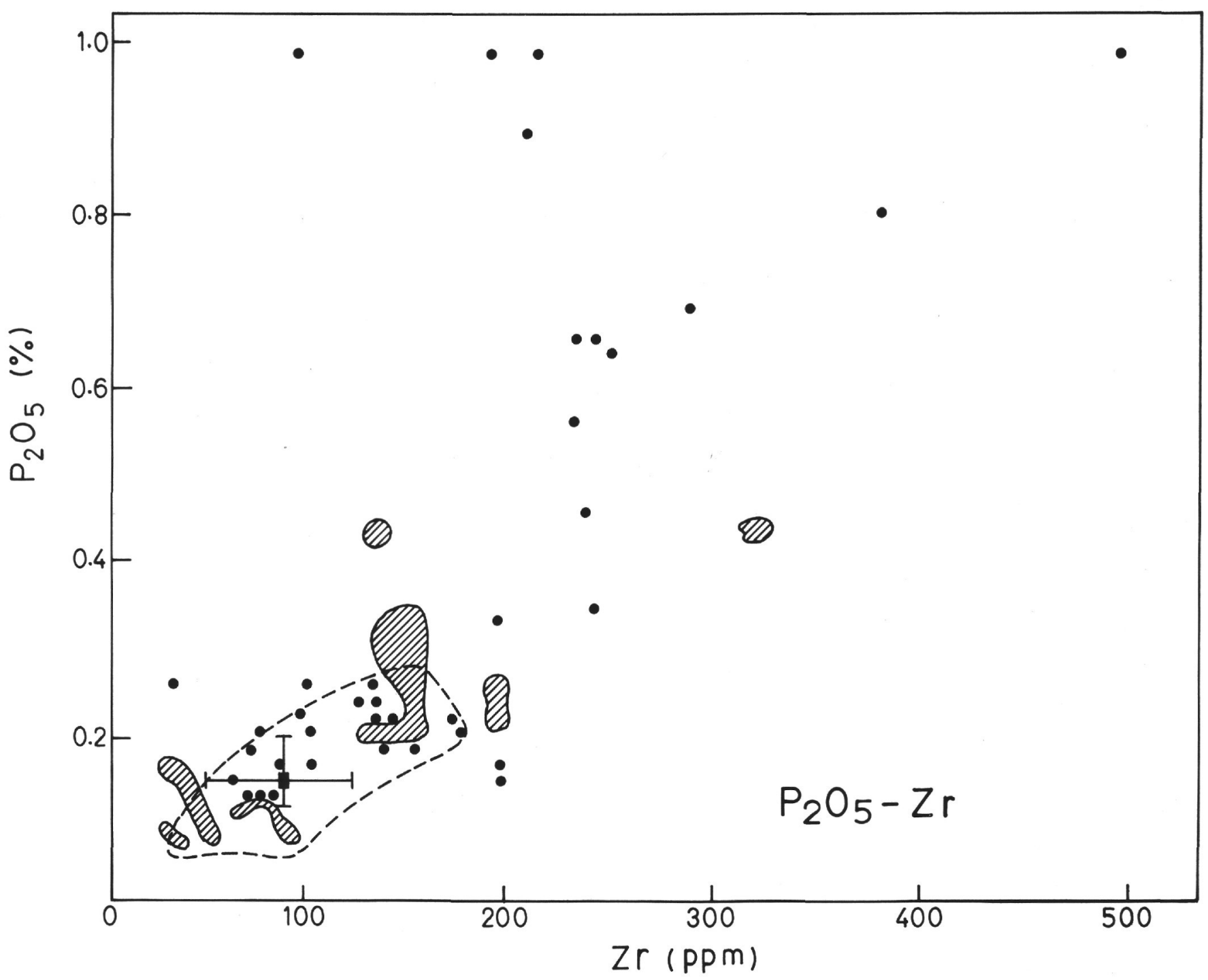

Figure 8. (Continued). 


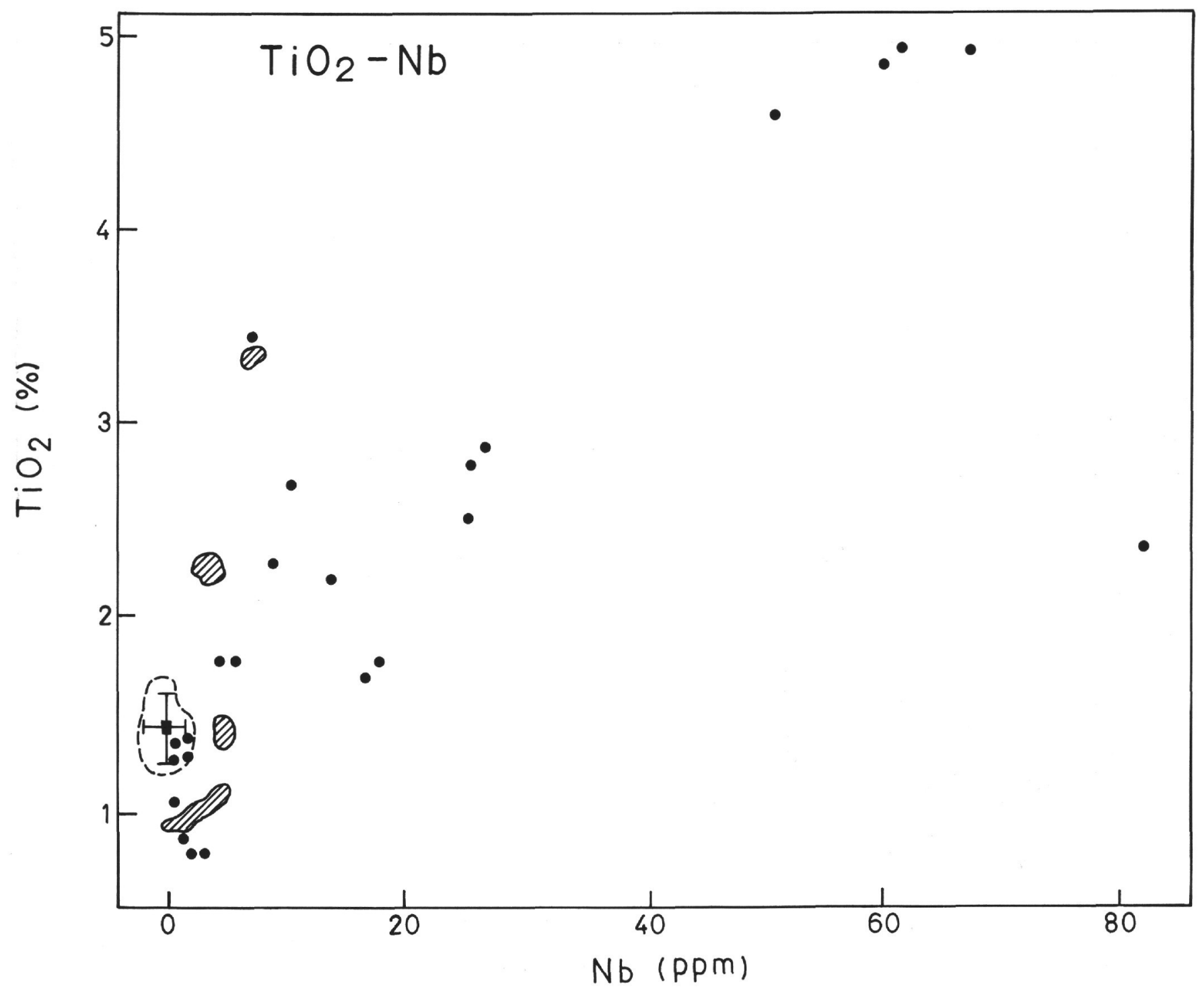

Figure 8. (Continued). 


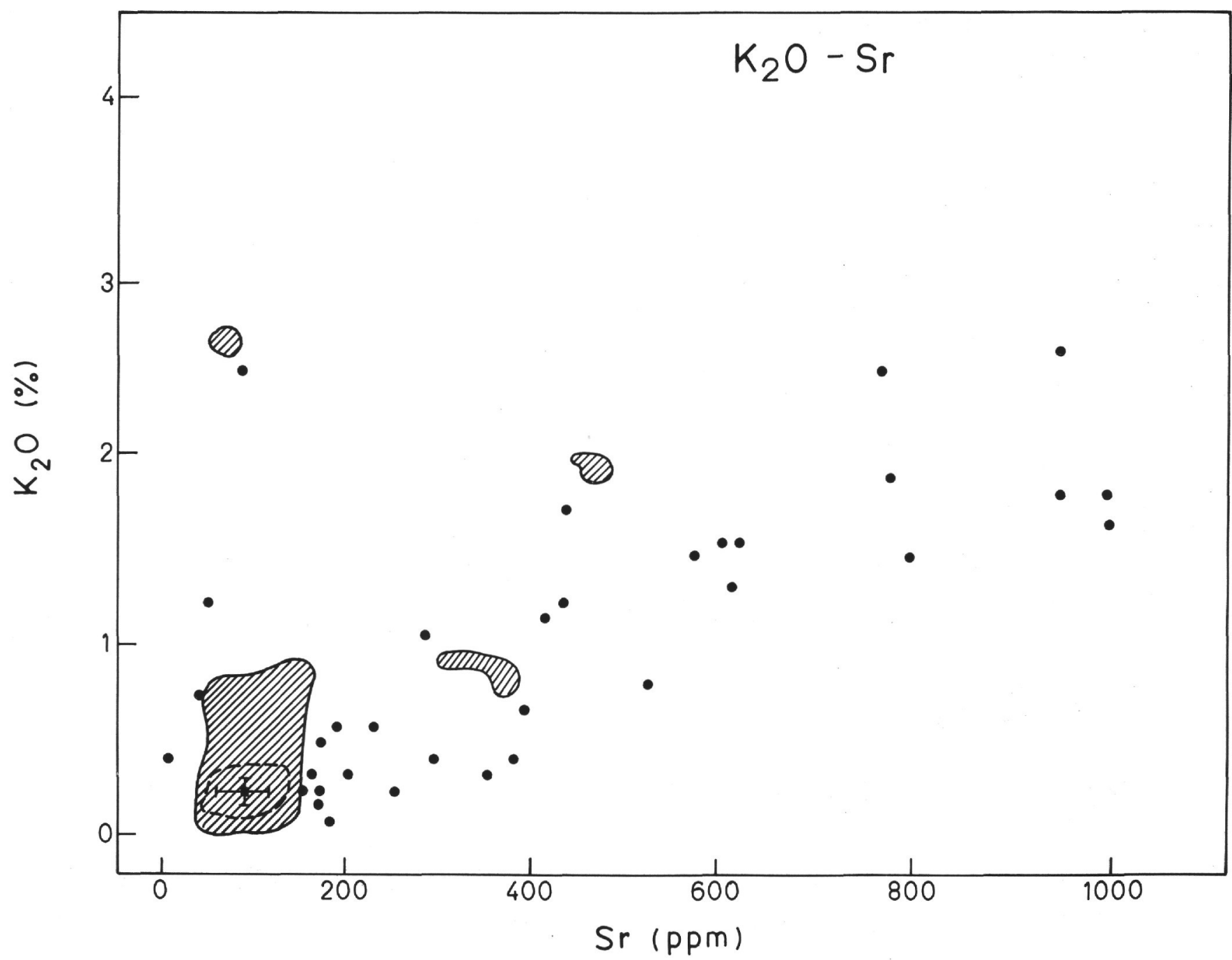

Figure 8. (Continued). 


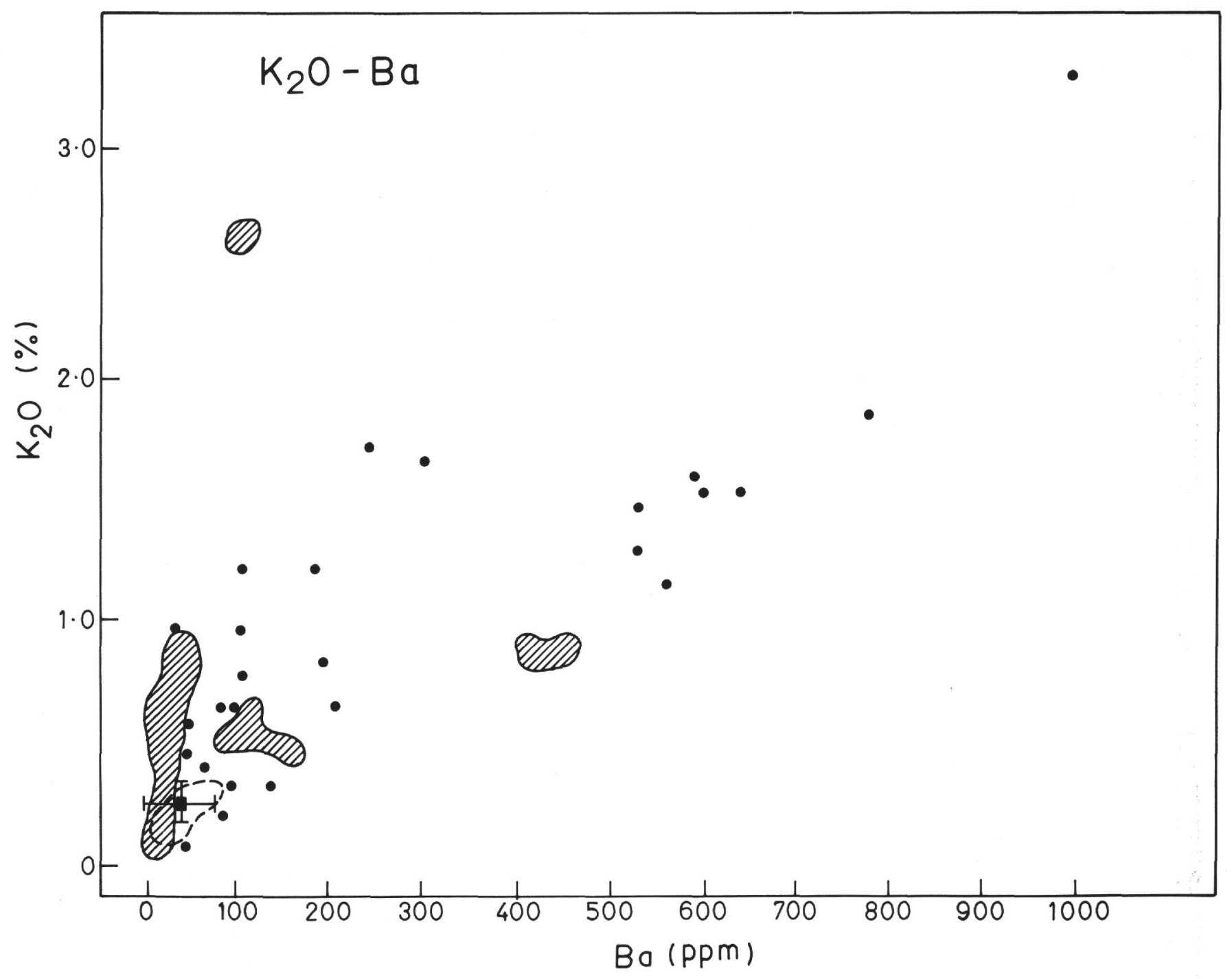

Figure 8. (Continued). 


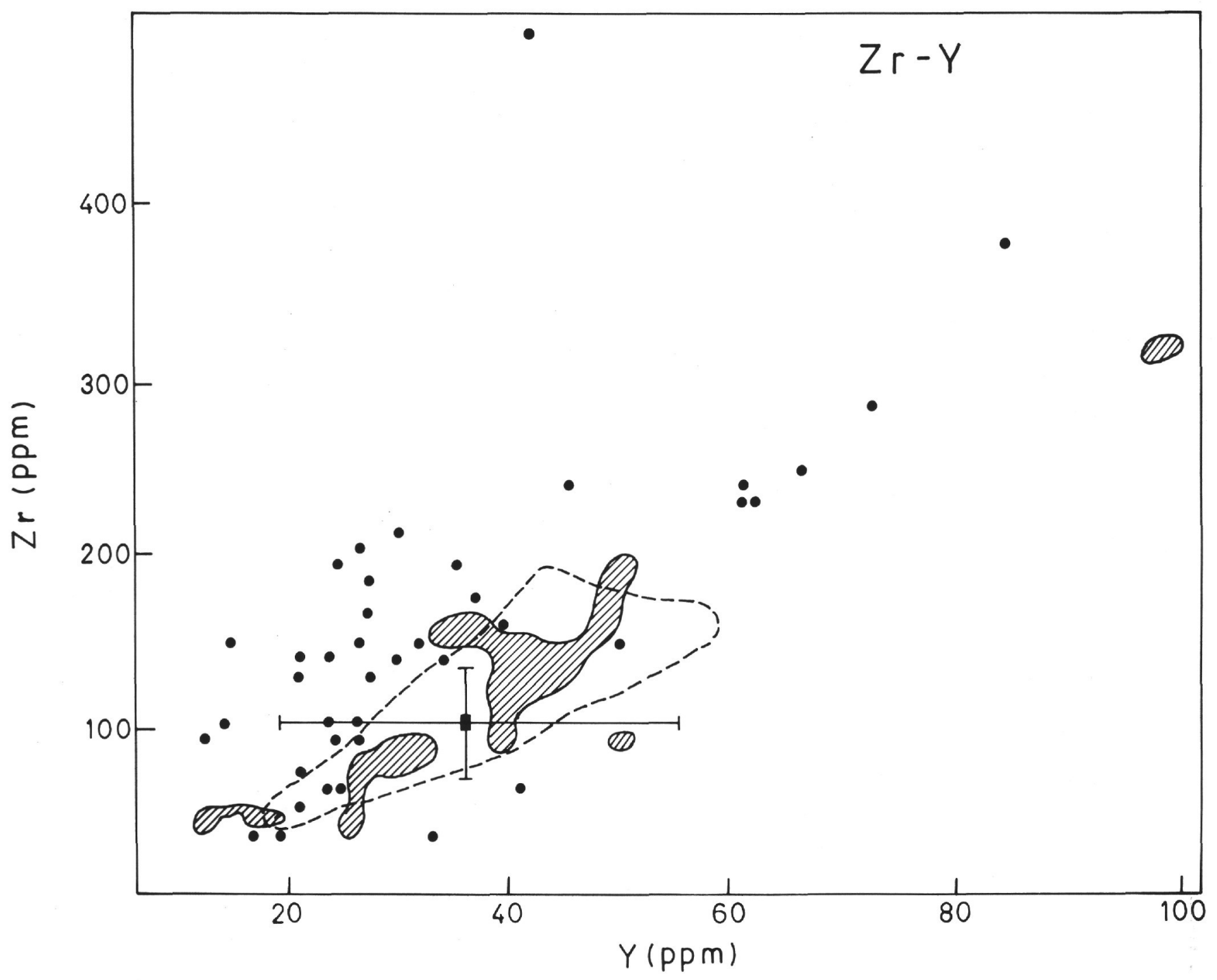

Figure 9. Covariant relations of LIL elements thought to be produced by partial melting of late magmatic phases. The crosses represent the means and standard deviations of MORB. The dashed line outlines the MORB field. Shaded areas enclose TOPS basalt. The dots represent all DSDP basement samples not classified as TOPS. 


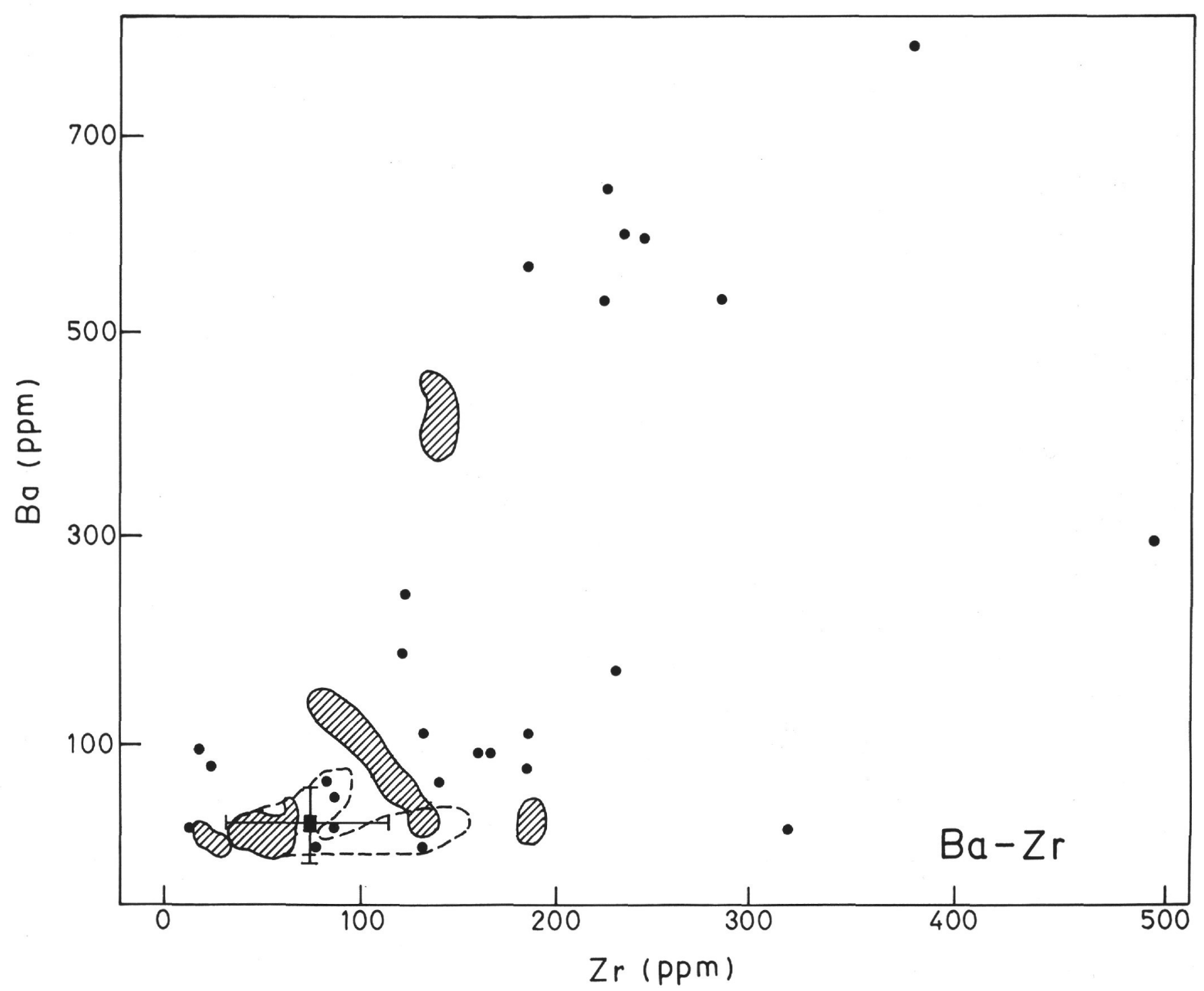

Figure 9. (Continued). 


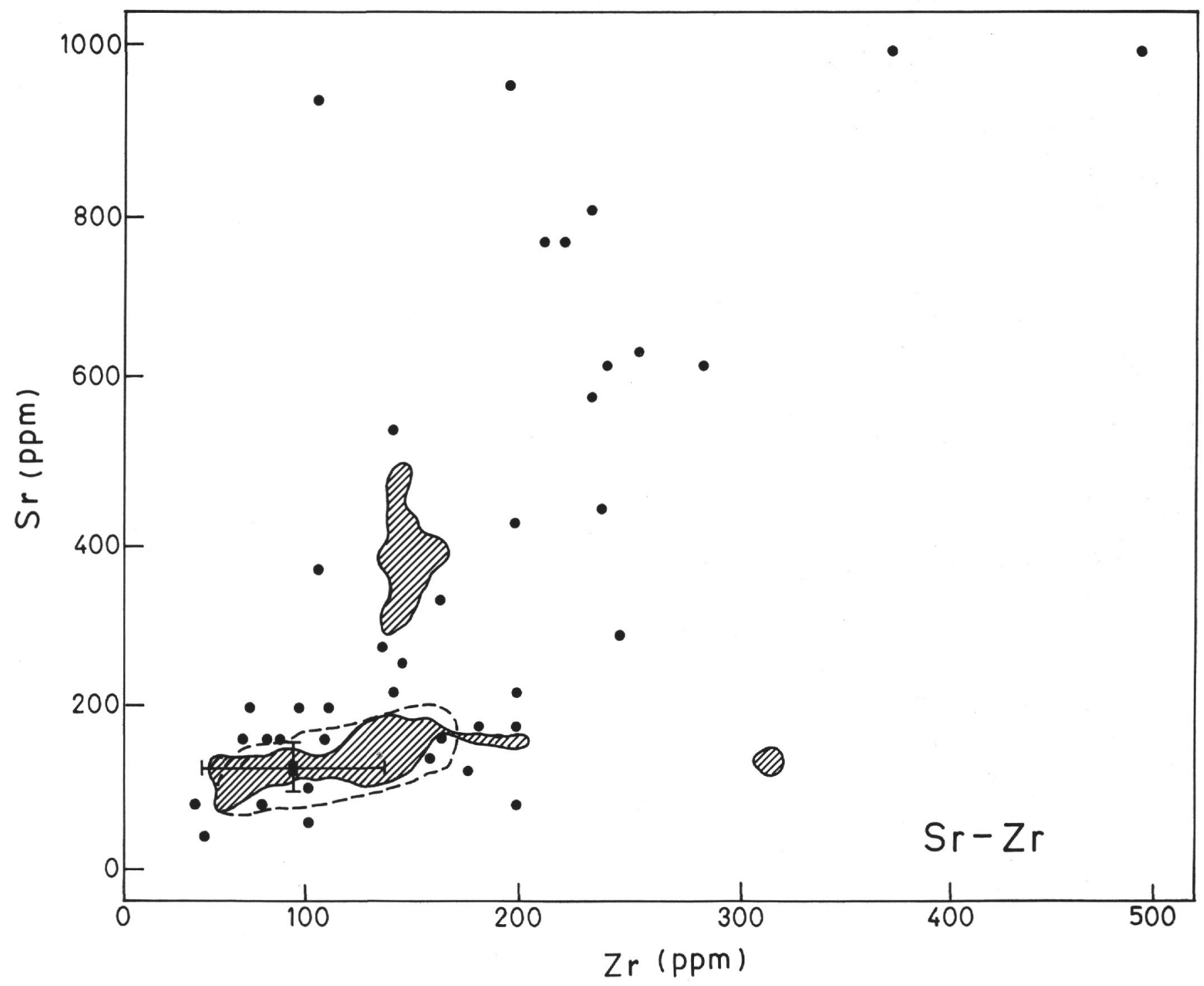

Figure 9. (Continued). 


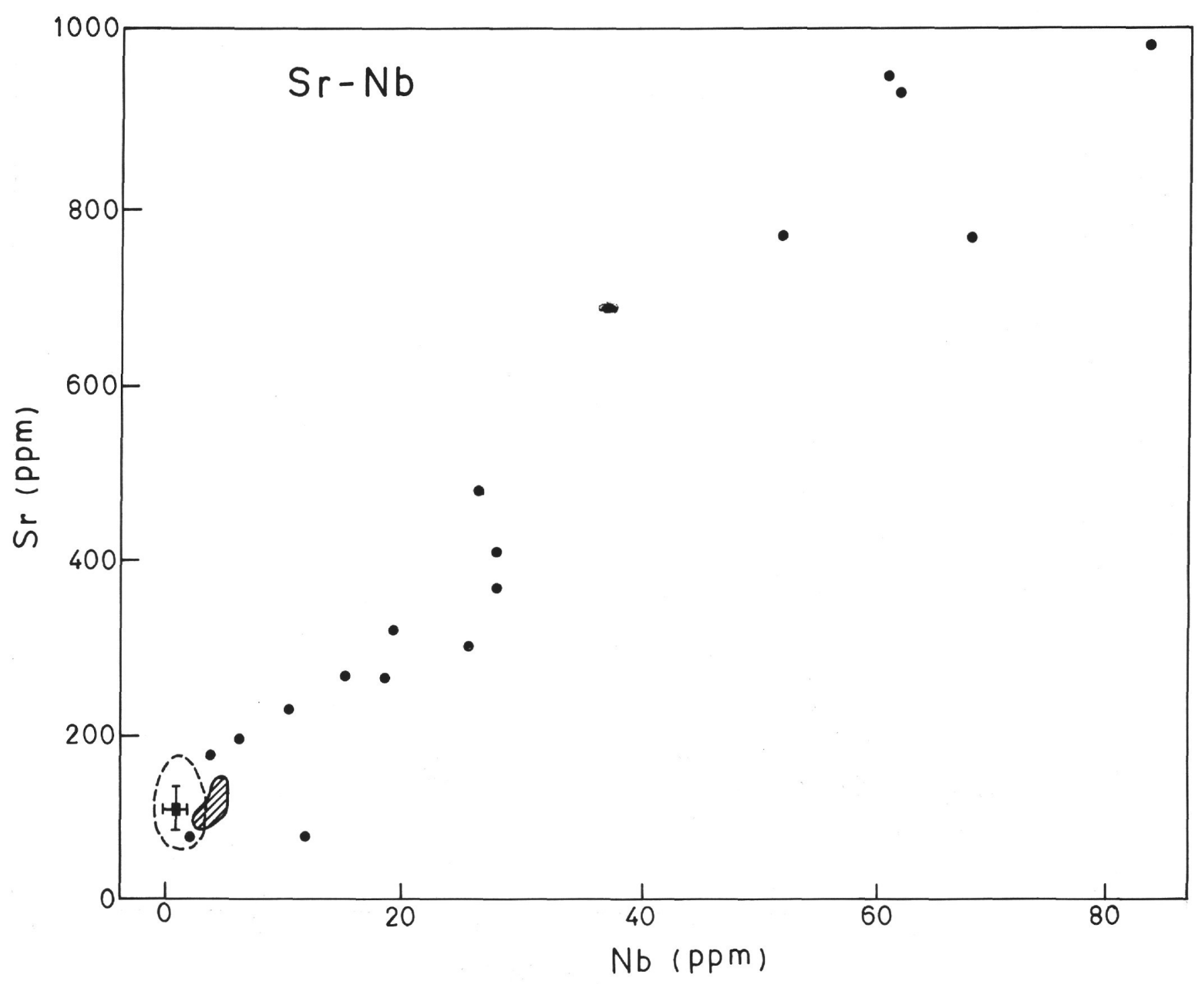

Figure 9. (Continued). 


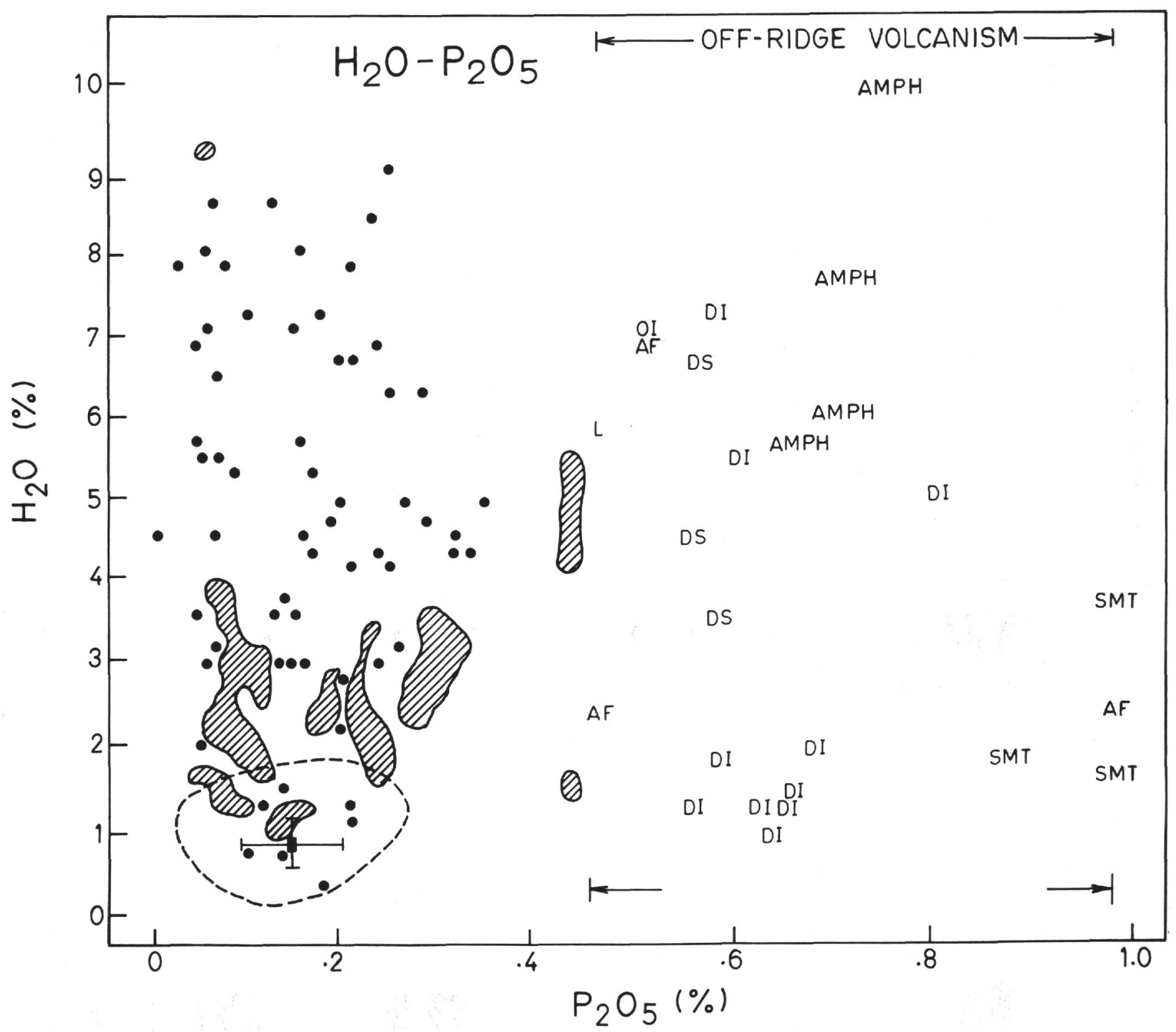

Figure 10. Plots of $\mathrm{H}_{2} \mathrm{O}$ versus $\mathrm{P}_{2} \mathrm{O}_{5}$ and $\mathrm{Al}_{2} \mathrm{O}_{3}$ versus $\mathrm{P}_{2} \mathrm{O}_{5}$ demonstrating the lack of covariance in these groups of elements. The crosses represent the means and standard deviations of MORB. The dashed line encloses the MORB field. The shaded areas enclose TOPS basalt. The dots represent DSDP basement samples not classified as TOPS basalt. DI = differentiated intrusive, $D S=$ diabase sill, $A L=$ alkalic flow, $P=$ picrite, $L=$ lamprophyre, $S M T=$ alkali basalt from seamount. 


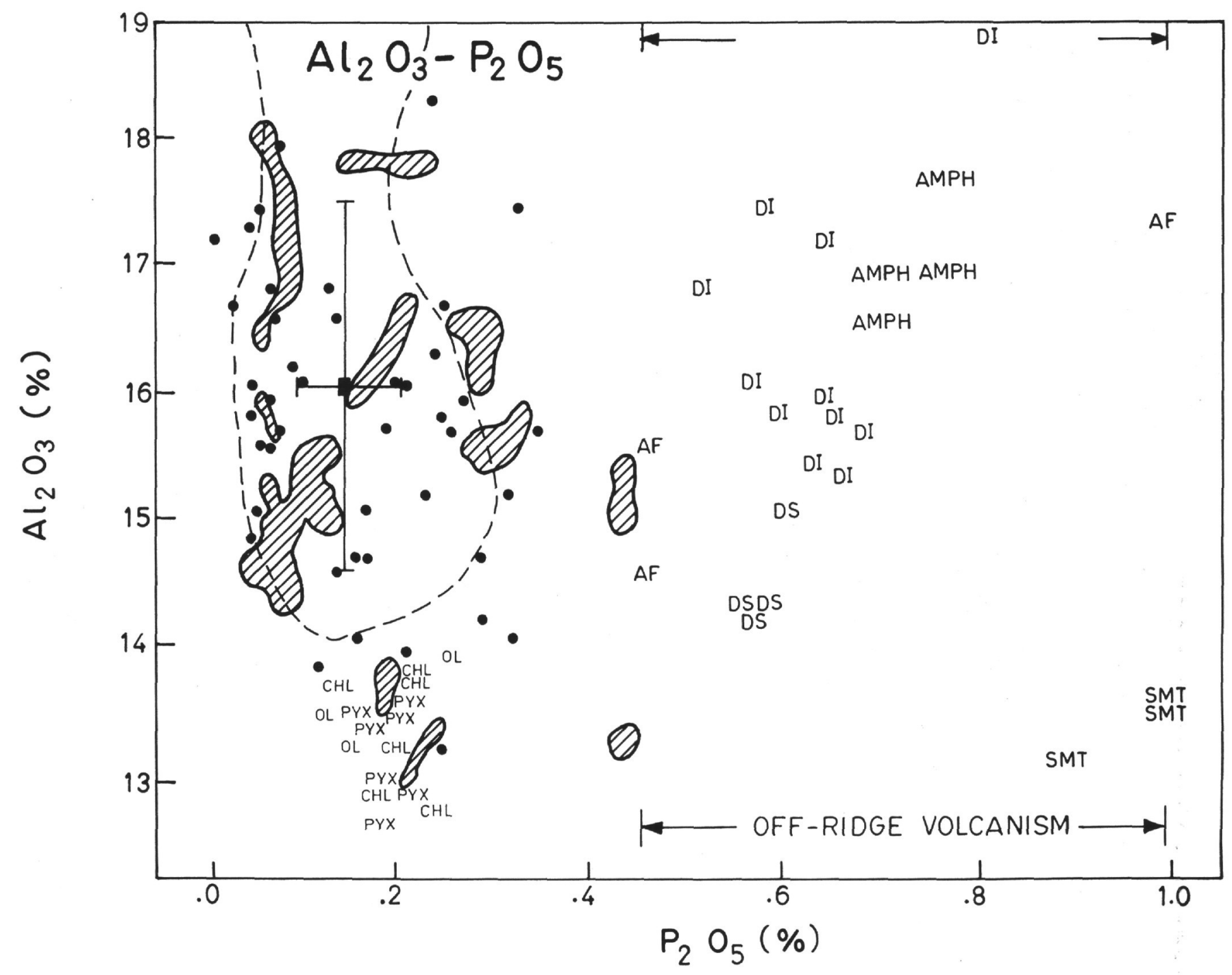

Figure 10. (Continued). 


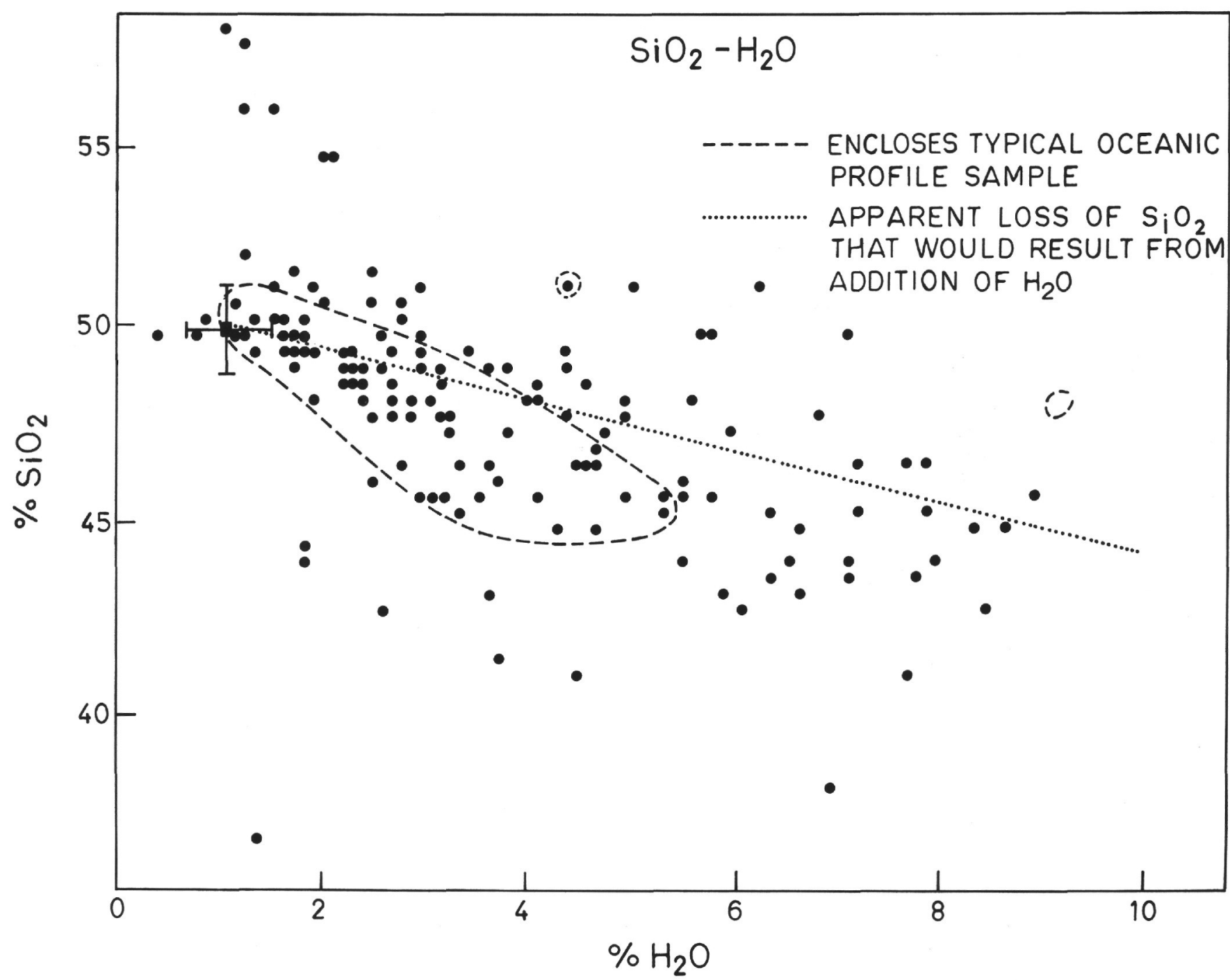

Figure 11. Covariant relations thought to be produced by seawater alteration of oceanic basalt. The crosses represent the mean and standard deviation of MORB. The dashed line encloses TOPS basalt. The dots represent all DSDP basement samples including TOPS basalt. The dotted lines represent the apparent losses in wt \% SiO $\mathrm{O}_{2}$ and $\mathrm{CaO}$ that would result from the addition of $10 \%$ by weight of $\mathrm{H}_{2} \mathrm{O}$ in a constant volume process. 


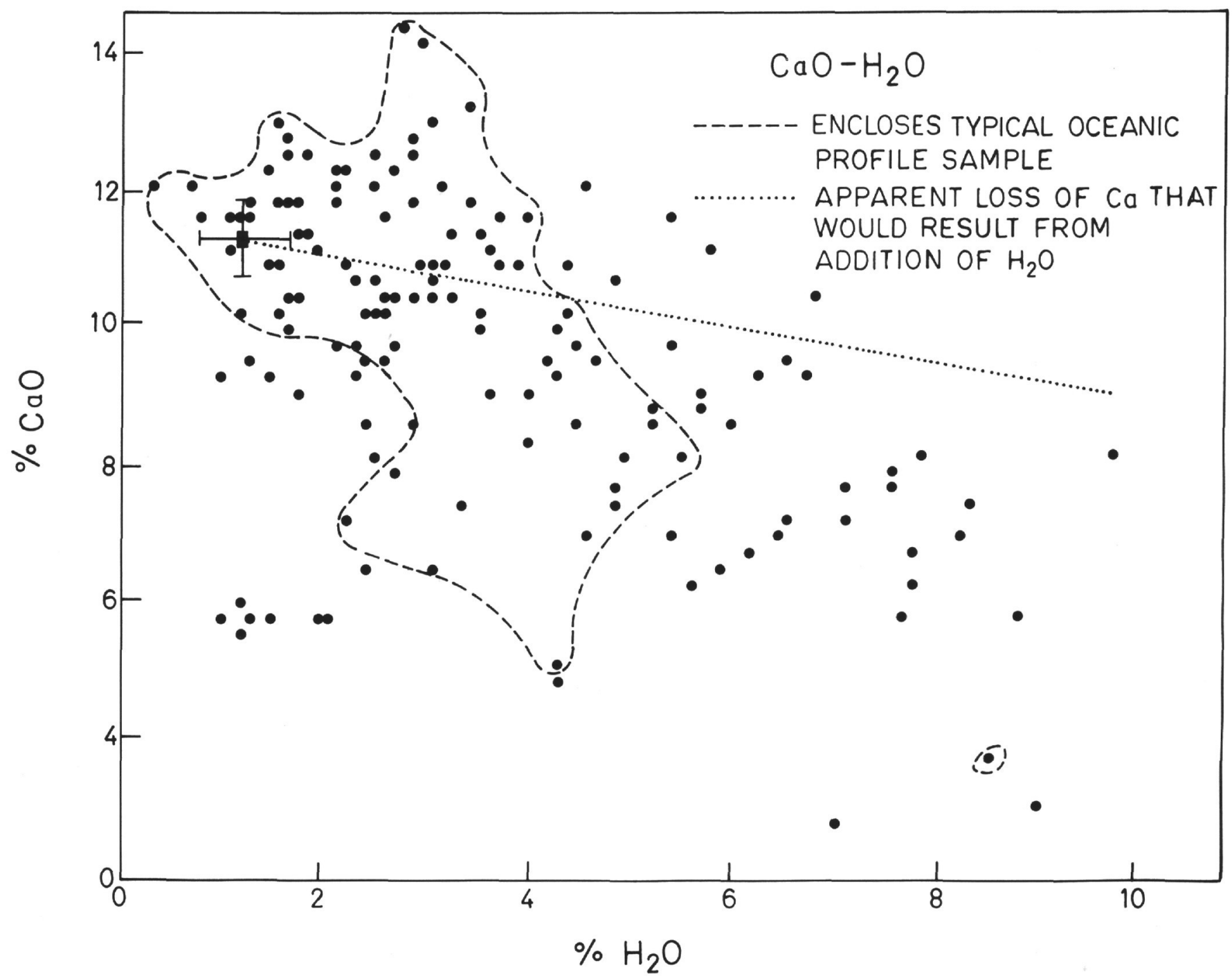

Figure 11. (Continued) 


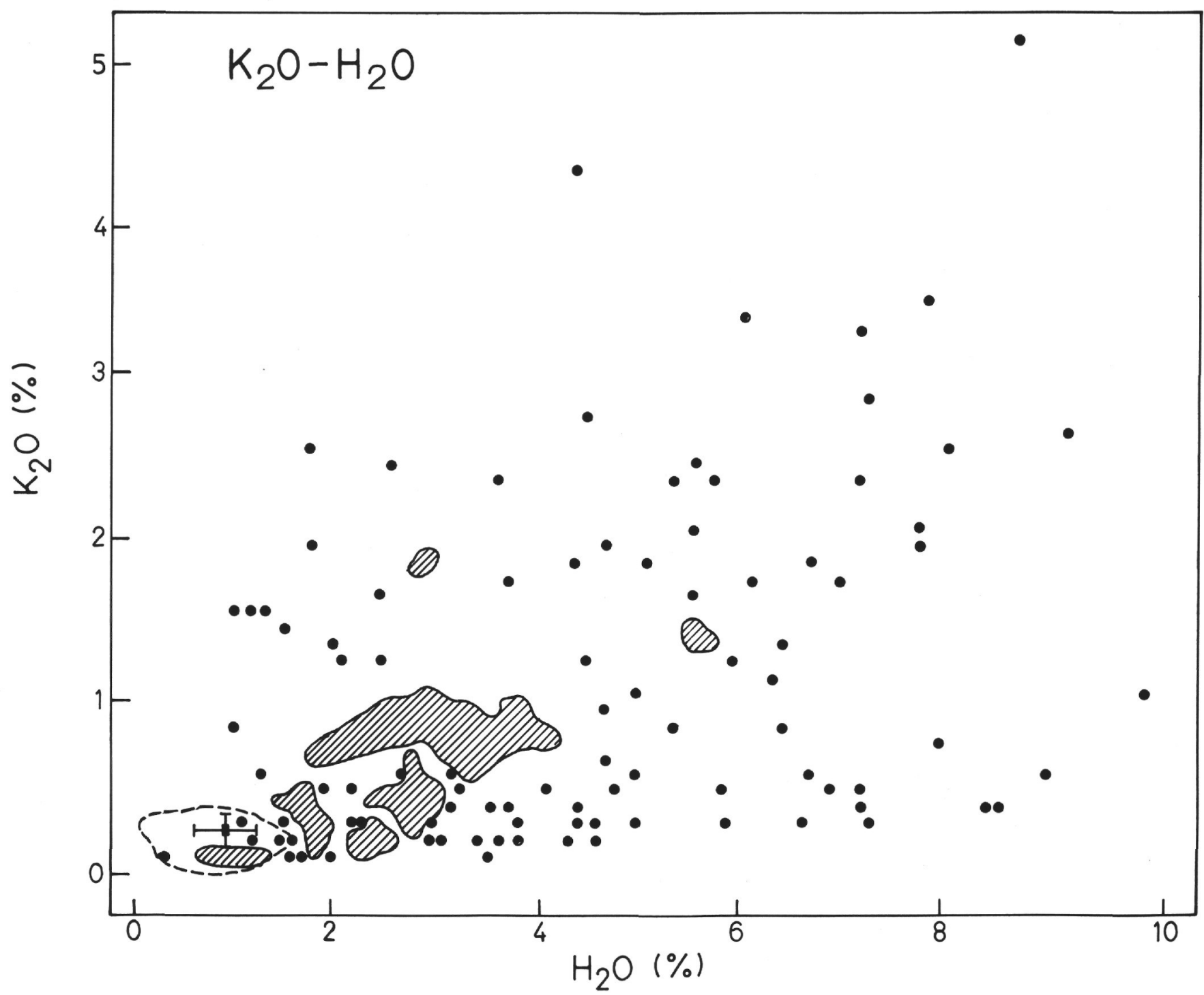

Figure 12. Covariant relations thought to be produced by seawater alteration of oceanic basalt. The crosses represent the means and standard deviation of MORB. The dashed line encloses MORB. The shaded areas enclose TOPS basalts. The dots represent all DSDP basement samples not classified as TOPS. 


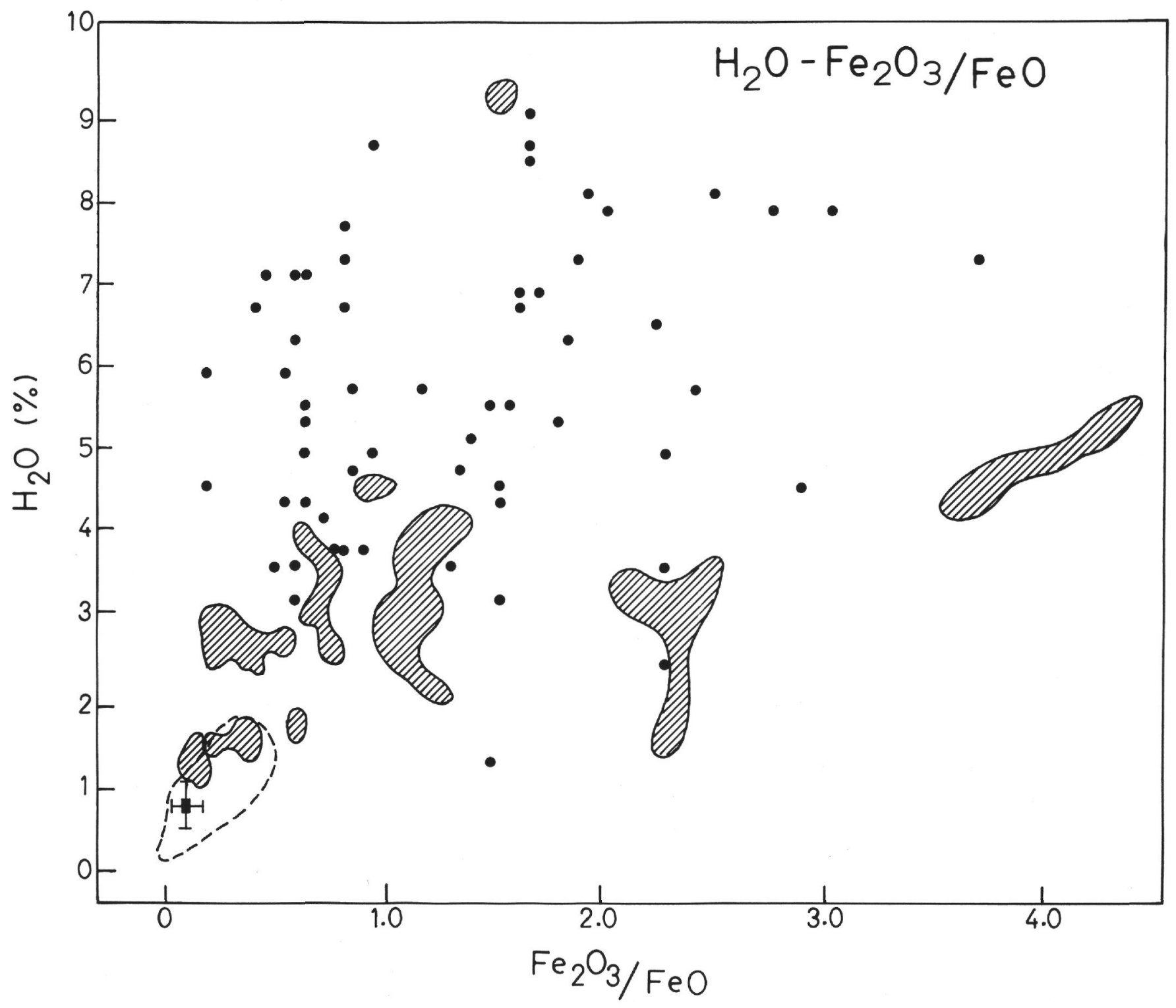

Figure 12. (Continued). 
TABLE 5

Results of Multiple Regression Analysis of the Dependency of Element Concentration in Oceanic Basalt (All DSDP Basement Samples Plus MORB) on $\mathrm{Al}_{2} \mathrm{O}_{3}, \mathrm{P}_{2} \mathrm{O}_{5}$, and $\mathrm{H}_{2} \mathrm{O}$ as Independent Variables

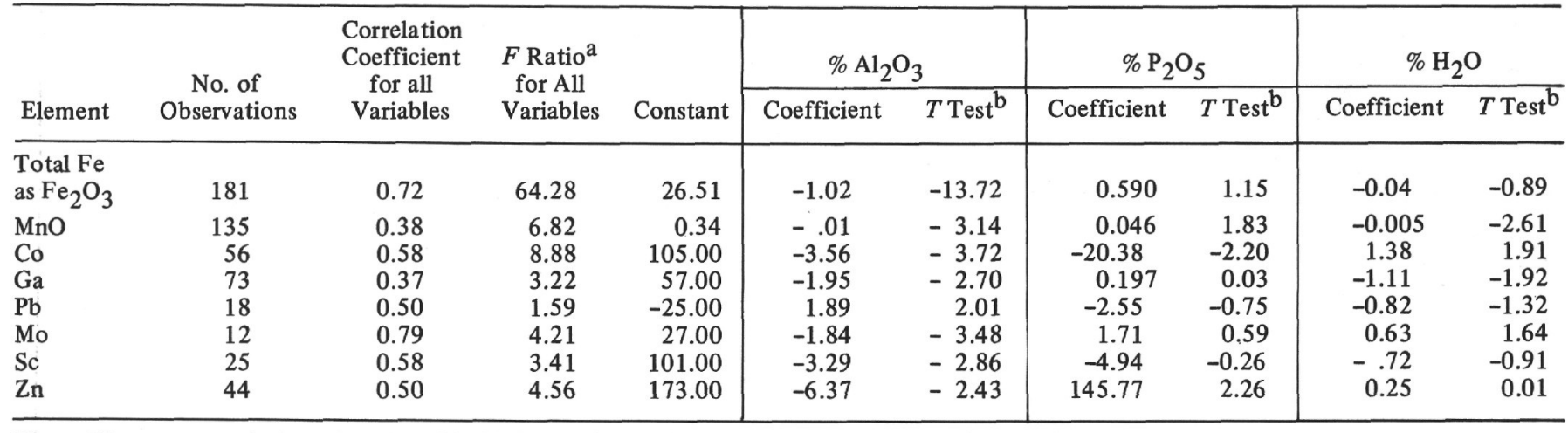

Note: Elements correlating primarily with $\mathrm{Al}_{2} \mathrm{O}_{3}$, major oxides in weight percent trace elements in ppm.

${ }^{a} F$ ratio shows significance at the $95 \%$ confidence level above 2.68 for more than 120 observations and above 2.93 for more than 30 observations.

$\mathrm{b}_{T}$ test shows significance at the $95 \%$ confidence level above 1.98 for more than 120 observations and above 2.04 for more than 30 observations.

TABLE 6

Results of Multiple Regression Analysis of the Dependency of Element Concentrations in Oceanic Basalt (All DSDP Basement Samples plus MORB) on $\mathrm{Al}_{2} \mathrm{O}_{3}, \mathrm{P}_{2} \mathrm{O}_{5}$, and $\mathrm{H}_{2} \mathrm{O}$ as Independent Variable

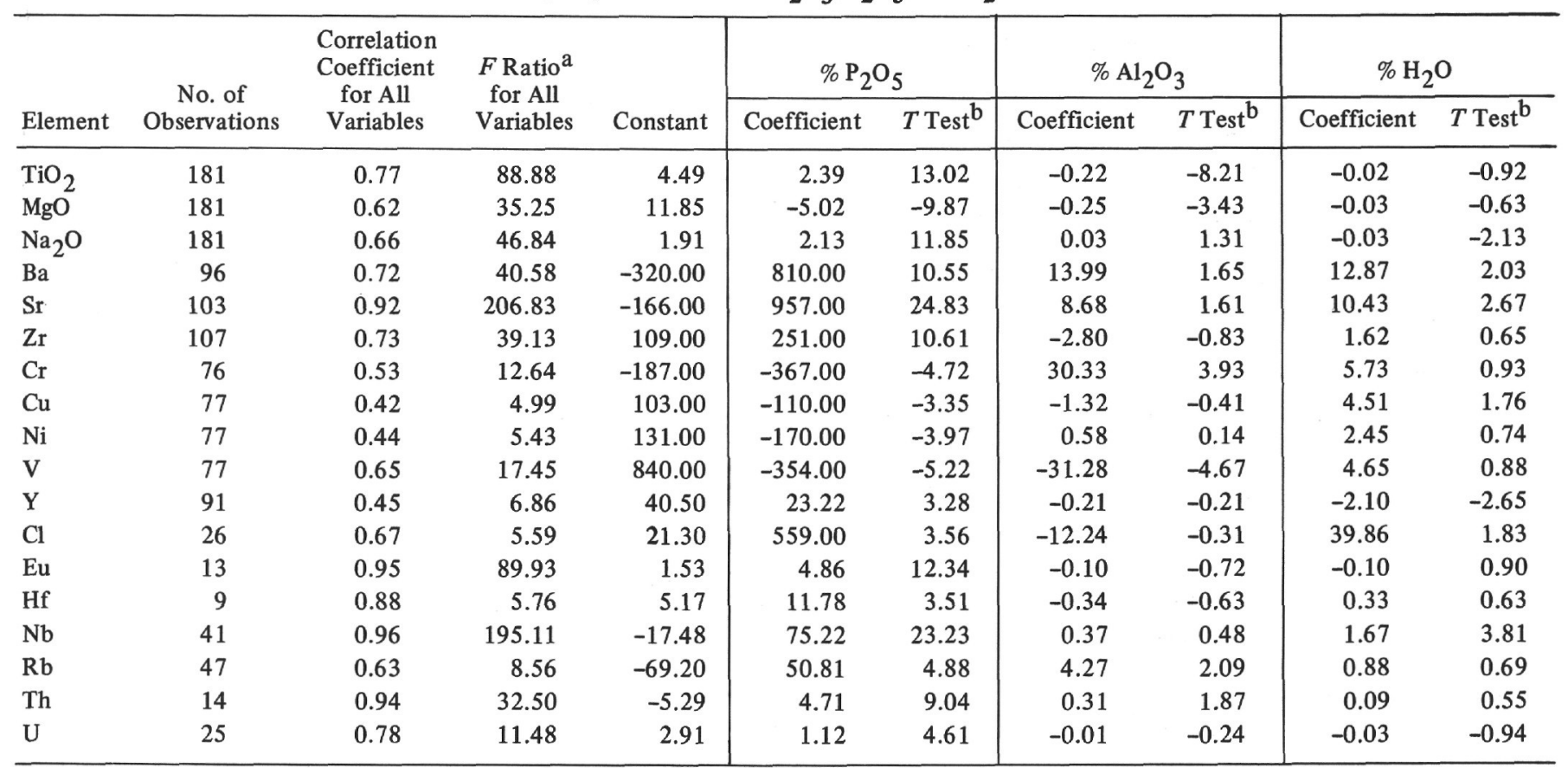

Note: Elements correlating primarily with $\mathrm{P}_{2} \mathrm{O}_{5}$, major oxides in weight percent trace elements in ppm.

${ }^{a} F$ ratio shows significance at the $95 \%$ confidence level above 2.68 for more than 120 observations and above 2.93 for more than 30 observations.

${ }^{b} T$ test shows significance at the $95 \%$ confidence level above 1.98 for more than 120 observations and above 2.04 for more than 30 observations. 
TABLE 7

Results of Multiple Regression Analysis of the Dependency of Element Concentrations in Oceanic Basalt (All DSDP Basement Samples Plus MORB) on $\mathrm{Al}_{2} \mathrm{O}_{3}, \mathrm{P}_{2} \mathrm{O}_{5}$, and $\mathrm{H}_{2} \mathrm{O}$ as Independent Variables

\begin{tabular}{|c|c|c|c|c|c|c|c|c|c|c|}
\hline \multirow[b]{2}{*}{ Element } & \multirow{2}{*}{$\begin{array}{c}\text { No. of } \\
\text { Observations }\end{array}$} & \multirow{2}{*}{$\begin{array}{c}\text { Correlation } \\
\text { Coefficient } \\
\text { for All } \\
\text { Variables }\end{array}$} & \multirow{2}{*}{$\begin{array}{c}F \text { Ratio } \\
\text { for All } \\
\text { Variables }\end{array}$} & \multirow[b]{2}{*}{ Constant } & \multicolumn{2}{|c|}{$\% \mathrm{H}_{2} \mathrm{O}$} & \multicolumn{2}{|c|}{$\% \mathrm{Al}_{2} \mathrm{O}_{3}$} & \multicolumn{2}{|c|}{$\% \mathrm{P}_{2} \mathrm{O}_{5}$} \\
\hline & & & & & Coefficient & $T$ Test $^{\mathrm{b}}$ & Coefficient & $T$ Test $^{\mathrm{b}}$ & Coefficient & $T$ Test $^{\mathrm{b}}$ \\
\hline $\mathrm{CaO}$ & 181 & 0.70 & 55.97 & 11.11 & -0.49 & -4.17 & 0.08 & 0.99 & -4.17 & -7.11 \\
\hline $\mathrm{K}_{2} \mathrm{O}$ & 181 & 0.69 & 52.90 & -1.19 & 0.17 & 8.20 & 0.06 & 1.74 & 1.97 & 8.20 \\
\hline
\end{tabular}

Note: Elements correlating primarily with $\mathrm{H}_{2} \mathrm{O}$, major element oxides in weight percent, trace elements in ppm.

${ }^{a} F$ ratio shows significance at the $95 \%$ confidence level above 2.68 for more than 120 observations and above 2.93 for more than 30 observations.

$\mathrm{b}_{T}$ test shows significance at the $95 \%$ confidence level above 1.98 for more than 120 observations and above 2.04 for more than 30 observations.

TABLE 8

Classification of Elements in Oceanic Basalt According to Degree of Correlation with Al-FeTi Group, LIL Group, and Seawater Alteration Group

\begin{tabular}{|c|c|c|c|}
\hline & Al-FeTi Group & LIL Group & Alteration Group \\
\hline Primary correlation & $\begin{array}{l}\mathrm{Al}, \mathrm{Fe}, \mathrm{Ti}, \mathrm{Co}, \mathrm{Sc} \\
\mathrm{Pb}, \mathrm{Ga}, \mathrm{Mo}, \mathrm{Mn}\end{array}$ & $\begin{array}{l}\mathrm{P}, \mathrm{Ti}, \mathrm{Na}, \mathrm{Zr}, \mathrm{Sr} \\
\mathrm{Ba}, \mathrm{Cl}, \mathrm{Hf}, \mathrm{Eu}, \mathrm{Nb} \\
\mathrm{Th}, \mathrm{U}, \mathrm{Rb}, \mathrm{Mg}, \mathrm{Cr} \\
\mathrm{Ni}, \mathrm{V}\end{array}$ & $\begin{array}{l}\mathrm{K}, \mathrm{Si}, \mathrm{Ca}, \mathrm{Li}, \mathrm{Cl} \\
\mathrm{H}_{2} \mathrm{O}, \mathrm{B}\end{array}$ \\
\hline Secondary correlation & $\begin{array}{l}\mathrm{Mg}, \mathrm{Si}, \mathrm{Zn}, \mathrm{Ni}, \mathrm{Rb} \\
\mathrm{Th}, \mathrm{Y}, \mathrm{B}, \mathrm{Yb}, \mathrm{V}, \mathrm{Cr}\end{array}$ & $\begin{array}{l}\mathrm{Si}, \mathrm{Co}, \mathrm{Zn}, \mathrm{Ca}, \mathrm{Y} \\
\mathrm{Cu}, \mathrm{Yb}, \mathrm{K}\end{array}$ & $\begin{array}{l}\mathrm{Na}, \mathrm{Mn}, \mathrm{Ba}, \mathrm{Rb}, \mathrm{Pb}, \\
\mathrm{Sr}, \mathrm{Mg}, \mathrm{Yb}, \mathrm{Eu}, \mathrm{Zn}, \\
\text { Th, U, Ga, Nb, Cr, Cu, Mo }\end{array}$ \\
\hline No correlation & $\begin{array}{l}\mathrm{Eu}, \mathrm{Sr}, \mathrm{Ba}, \mathrm{K}, \mathrm{Na} \\
\mathrm{Cu}, \mathrm{Cl}, \mathrm{Hf}, \mathrm{Li}, \mathrm{Nb} \text {, } \\
\mathrm{U}, \mathrm{H}_{2} \mathrm{O}\end{array}$ & $\begin{array}{l}\mathrm{Mn}, \mathrm{Ga}, \mathrm{Li}, \mathrm{Rb} \\
\mathrm{Mo}, \mathrm{Sc}, \mathrm{Al}, \mathrm{Fe}, \mathrm{B}\end{array}$ & $\begin{array}{l}\mathrm{Zr}, \mathrm{Ti}, \mathrm{Co}, \mathrm{Ni}, \mathrm{V} \\
\mathrm{Hf}, \mathrm{Sc}, \mathrm{Al}, \mathrm{Fe}\end{array}$ \\
\hline
\end{tabular}

TABLE 9

Results of Multiple Regression Analysis of the Dependence of Elemental Abundances in Oceanic Basalt

(All DSDP Basement Samples Plus MORB) on the Age of the Oceanic Crust (as Determined Paleontologically in the Oldest Overlying Sediment) and Depth of Drill Penetration Into Basement

\begin{tabular}{|c|c|c|c|c|c|c|c|}
\hline \multirow[b]{2}{*}{ Element } & \multirow{2}{*}{$\begin{array}{c}\text { No. of } \\
\text { Observations }\end{array}$} & \multirow{2}{*}{$\begin{array}{c}\text { Correlation } \\
\text { Coefficient } \\
\text { for All } \\
\text { Variables }\end{array}$} & \multirow{2}{*}{$\begin{array}{c}F \text { Ratio }^{\mathrm{a}} \\
\text { for All } \\
\text { Variables }\end{array}$} & \multicolumn{2}{|c|}{ Age $\left(10^{8} y r\right)$} & \multicolumn{2}{|c|}{ Depth $(10 \mathrm{~m})$} \\
\hline & & & & Coefficient & $T$ Test $^{\mathrm{b}}$ & Coefficient & $T$ Test $^{\mathrm{b}}$ \\
\hline $\mathrm{CaO}$ & 193 & 0.38 & 13.21 & -1.82 & -5.01 & 0.43 & 2.98 \\
\hline $\mathrm{K}_{2} \mathrm{O}$ & 193 & 0.37 & 12.49 & 0.71 & 4.93 & -0.15 & -2.68 \\
\hline $\mathrm{Na}_{2} \mathrm{O}$ & 193 & 0.36 & 11.40 & 0.33 & 3.07 & -0.20 & -4.56 \\
\hline $\mathrm{SiO}_{2}$ & 193 & 0.25 & 6.00 & -1.80 & -3.44 & 0.35 & 1.70 \\
\hline $\mathrm{Al}_{2} \mathrm{O}_{3}$ & 193 & 0.19 & 3.28 & -0.52 & -2.06 & -0.06 & -0.60 \\
\hline $\mathrm{Y}$ & 88 & 0.28 & 3.15 & -8.51 & -2.08 & 0.21 & 1.82 \\
\hline $\mathrm{Pb}$ & 18 & 0.50 & 2.60 & -2.20 & -1.86 & 0.03 & 4.11 \\
\hline
\end{tabular}

Note: Major oxides in weight percent, trace elements in ppm.

${ }^{\mathrm{a}} F$ ratio shows significance at the $95 \%$ confidence level above 2.68 for more than 120 observations and above 2.93 for more than 30 observations.

$\mathrm{b}_{T}$ test shows significance at the $95 \%$ confidence level above 1.98 for more than 120 observations and above 2.04 for more than 30 observations. 
TABLE 10

Results of Multiple Regression Analysis of the Dependence of Element Abundance in TOPS Basalt and MORB on the Age of the Oceanic Crust (as Determined Paleontologically in the Oldest Overlying Sediment) and Depth of Drill Penetration Into Basement

\begin{tabular}{|c|c|c|c|c|c|c|c|}
\hline \multirow[b]{2}{*}{ Element } & \multirow{2}{*}{$\begin{array}{c}\text { No. of } \\
\text { Observations }\end{array}$} & \multirow{2}{*}{$\begin{array}{l}\text { Correlation } \\
\text { Coefficient } \\
\text { for All } \\
\text { Variables }\end{array}$} & \multirow{2}{*}{$\begin{array}{c}F \text { Ratio }^{\mathrm{a}} \\
\text { for All } \\
\text { Variables }\end{array}$} & \multicolumn{2}{|c|}{ Age $\left(10^{8} \mathrm{yr}\right)$} & \multicolumn{2}{|c|}{ Depth $(10 \mathrm{~m})$} \\
\hline & & & & Coefficient & $T$ Test $^{\mathrm{b}}$ & Coefficient & $T$ Test $^{\mathrm{b}}$ \\
\hline $\mathrm{Na}_{2} \mathrm{O}$ & 102 & 0.55 & 19.06 & 0.25 & 2.53 & -0.20 & -6.00 \\
\hline $\mathrm{K}_{2} \mathrm{O}$ & 102 & 0.53 & 18.15 & 0.54 & 6.02 & -0.13 & -4.02 \\
\hline $\mathrm{SiO}_{2}$ & 102 & 0.38 & 7.58 & -1.42 & -3.87 & 0.35 & 2.80 \\
\hline $\mathrm{TiO}_{2}$ & 102 & 0.37 & 7.48 & 0.35 & 2.62 & -0.18 & -3.86 \\
\hline $\mathrm{MgO}$ & 102 & 0.36 & 7.04 & -1.06 & -3.36 & 0.38 & 3.42 \\
\hline $\mathrm{MnO}$ & 85 & 0.36 & 6.40 & 0.04 & 3.35 & -0.01 & -1.15 \\
\hline $\mathrm{CaO}$ & 102 & 0.31 & 5.38 & -1.21 & -3.11 & 0.37 & 2.77 \\
\hline $\mathrm{P}_{2} \mathrm{O}_{5}$ & 87 & 0.31 & 4.23 & 0.04 & 1.69 & -0.02 & -2.90 \\
\hline $\mathrm{Cu}$ & 42 & 0.58 & 9.67 & -4.79 & -3.25 & 0.27 & 0.08 \\
\hline $\mathrm{Nb}$ & 16 & 0.73 & 6.96 & 3.93 & 3.69 & -0.11 & -2.45 \\
\hline $\mathrm{Li}$ & 25 & 0.61 & 6.26 & 5.27 & 3.08 & -2.81 & -0.73 \\
\hline V & 39 & 0.42 & 3.82 & 92.00 & 2.70 & -12.26 & 1.48 \\
\hline Hf & 6 & 0.84 & 3.50 & 0.46 & 1.23 & -1.52 & -2.32 \\
\hline $\mathrm{Rb}$ & 20 & 0.52 & 3.09 & 3.46 & 2.23 & -0.50 & -0.26 \\
\hline
\end{tabular}

Note: Major oxides in weight percent, trace elements in ppm.

${ }^{a} F$ ratio shows significance at the $95 \%$ confidence level above 2.68 for more than 120 observations and above 2.93 for more than 30 observations.

${ }^{b_{T}} T$ test shows significance at the $95 \%$ confidence level above 1.98 for more than 120 observations and above 2.04 for more than 30 observations.

\section{APPENDIX A: LITERATURE SOURCES FOR CHEMICAL DATA ON OCEANIC BASALT USED IN THIS STUDY}

1. DSDP Samples:

Sabine (1972); Wright et al. (1972); Honnorez and Fox (1973); Weibel and Hsü (1973); Donnelly et al. (1973); Bass et al. (1973); Yeats et al. (1973); MacLeod and Pratt (1973); Steward et al. (1973); Hekinian (1973); Thompson et al. (1973); Coleman (1974); Erlank et al. (1974); Kempe (1974); Ovenshine et al. (1975); Robinson and Whitford (1974).

\section{Ridge Basalts:}

Melson et al. (1968) Samples: 2-1 and 2-2.

Aumento (1968) Samples: 1-1, 1-3, 56-2, and 56-3.

Engel et al. (1965) Samples: AD-2, AD-3, AD5-5, AD5-1, PVD-1, PVD-3, PVD-4C.

Hart et al. (1974) Samples: AD-1 (core), AD3-3 (glass), AD5-18 (margin).

Kay et al. (1970) Samples:AD150-7-4C, AD150-2-20, 13E, KD11,
Miyashiro et al (1969) Samples: A150-AM9, A150-AM1, A150. AM2, A150-AM5, A150-AM4, A150-AM15, A150-AM7, A150AM16, V251-T9, V251-T87, V251-T3, V251-T11, V251-T1C, V251T97, V251-T96, V251-T103, V251-T91, V251-T94, V251-T99, V251T102, V2510T89.

Hekinian (1971) Samples: RC8-91, RC8-91A, RC8913, RC10-243. Scheidegger (1972) Samples: W4-15, W8-2.

\section{APPENDIX B}

Correlation Matrices of Elemental Abundances in all DSDP Samples, TOPS Group, and Ridge Basalt

- $\quad$ = Strong negative correlation.

$++=$ Strong positive correlation, $R$ greater than 0.5 with $99 \%$ confidence.

- $\quad$ = Weak negative correlation.

$+\quad=$ Weak positive correlation, $R$ greater than 0.3 with $95 \%$ confidence.

$0=$ No correlation.

$\mathrm{ND}=$ No data. 
TABLE B1

All DSDP Data Correlation Matrix:

Major Elements, Physical Properties and Site Characteristics

\begin{tabular}{|c|c|c|c|c|c|c|c|c|c|c|c|c|c|c|c|c|c|c|c|c|c|}
\hline & & 1 & 2 & 3 & 4 & 5 & 6 & 7 & 8 & 9 & 10 & & 12 & 13 & & 15 & & 17 & & 19 & 20 \\
\hline 1 & Water depth & & 0 & + & 0 & 0 & 0 & 0 & 0 & 0 & 0 & 0 & 0 & 0 & 0 & 0 & + & 0 & 0 & 0 & 0 \\
\hline 2 & Sediment thickness & 0 & & 0 & 0 & 0 & 0 & 0 & 0 & 0 & 0 & 0 & - & 0 & 0 & - & 0 & 0 & 0 & 0 & 0 \\
\hline 3 & Age & + & 0 & & 0 & 0 & 0 & 0 & 0 & 0 & 0 & 0 & 0 & 0 & 0 & 0 & 0 & 0 & 0 & 0 & 0 \\
\hline 4 & Depth & 0 & 0 & 0 & & + & + & 0 & 0 & 0 & 0 & 0 & 0 & 0 & 0 & 0 & 0 & 0 & 0 & 0 & 0 \\
\hline 5 & Sonic velocity & 0 & 0 & 0 & + & & 0 & 0 & 0 & - & 0 & 0 & H & - & - & -- & 0 & 0 & 0 & & - \\
\hline 6 & Density & 0 & 0 & 0 & + & 0 & & 0 & 0 & -- & 0 & + & t+ & ++ & + & - & 0 & - & 0 & 0 & - \\
\hline 7 & $\mathrm{SiO}_{2}$ & 0 & 0 & 0 & 0 & 0 & 0 & & 0 & 0 & 0 & 0 & 0 & 0 & 0 & -- & 0 & 0 & 0 & 0 & 0 \\
\hline 8 & $\mathrm{Al}_{2} \mathrm{O}_{3}$ & 0 & 0 & 0 & 0 & 0 & 0 & 0 & & - & -- & 0 & 0 & 0 & 0 & 0 & 0 & 0 & 0 & -- & 0 \\
\hline 9 & $\mathrm{TiO}_{2}$ & 0 & 0 & 0 & 0 & - & -- & 0 & - & & + & 0 & 0 & + & 0 & 0 & & ++ & 0 & 0 & 0 \\
\hline 10 & Total iron as $\mathrm{Fe}_{2} \mathrm{O}_{3}$ & 0 & 0 & 0 & 0 & 0 & 0 & 0 & -- & + & & - & 0 & 0 & 0 & 0 & + & 0 & 0 & ++ & 0 \\
\hline 11 & $\mathrm{MgO}$ & 0 & 0 & 0 & 0 & 0 & + & 0 & 0 & 0 & - & & 0 & - & - & 0 & 0 & -- & 0 & 0 & 0 \\
\hline 12 & $\mathrm{CaO}$ & 0 & - & 0 & 0 & ++ & ++ & 0 & 0 & 0 & 0 & 0 & & - & -- & -- & 0 & - & 0 & 0 & - \\
\hline 13 & $\mathrm{Na}_{2} \mathrm{O}$ & 0 & 0 & 0 & 0 & - & ++ & 0 & 0 & + & 0 & - & - & & 0 & 0 & 0 & ++ & 0 & 0 & 0 \\
\hline 14 & $\mathrm{~K}_{2} \mathrm{O}$ & 0 & 0 & 0 & 0 & - & + & 0 & 0 & 0 & 0 & - & - & 0 & & + & 0 & + & 0 & - & + \\
\hline 15 & $\mathrm{H}_{2}^{2} \mathrm{O}$ & 0 & - & 0 & 0 & -- & -- & -- & 0 & 0 & 0 & 0 & -- & 0 & + & & 0 & 0 & 0 & - & + \\
\hline 16 & $\mathrm{MnO}$ & + & 0 & 0 & 0 & 0 & 0 & 0 & 0 & + & + & 0 & 0 & 0 & 0 & 0 & & 0 & 0 & 0 & 0 \\
\hline 17 & $\mathrm{P}_{2} \mathrm{O}_{5}$ & 0 & 0 & 0 & 0 & 0 & - & 0 & 0 & ++ & 0 & - & - & ++ & + & 0 & 0 & & 0 & 0 & 0 \\
\hline 18 & $\mathrm{Fe}_{2} \mathrm{O}_{3}$ & 0 & 0 & 0 & 0 & 0 & 0 & 0 & 0 & 0 & 0 & 0 & 0 & 0 & 0 & 0 & 0 & 0 & & 0 & 0 \\
\hline 19 & $\mathrm{FeO}$ & 0 & 0 & 0 & 0 & ++ & 0 & 0 & -- & 0 & t+ & 0 & 0 & 0 & - & - & 0 & 0 & 0 & & ++ \\
\hline 20 & $\mathrm{Fe}_{2} \mathrm{O}_{3} / \mathrm{FeO}$ & 0 & 0 & 0 & 0 & -- & - & 0 & 0 & 0 & 0 & 0 & - & 0 & + & + & 0 & 0 & 0 & ++ & \\
\hline
\end{tabular}

Note: $--=$ strong negative correlation; $++=$ strong positive correlation, $\mathrm{R}$ greater than 0.5 width $99 \%$ confidence; - = weak negative correlation; + = with positive correlation, greater than 0.3 with $95 \%$ confidence; $0=$ no correlation; $\mathrm{ND}=$ no data.

TABLE B2

All DSDP Data Correlation Matrix Major Properties Versus Trace Elements

\begin{tabular}{|c|c|c|c|c|c|c|c|c|c|c|c|c|c|c|c|c|c|c|c|c|c|c|c|c|}
\hline & $\mathrm{Ba}$ & $\mathrm{Sr}$ & $\mathrm{Zr}$ & $\mathrm{Cr}$ & & & & $\mathrm{Ni}$ & $\mathrm{V}$ & $\mathrm{Y}$ & B & $\mathrm{Cl}$ & Eu Hf & $\mathrm{Li}$ & $\mathrm{Pb}$ & Mo & $\mathrm{Nb}$ & $b$ & $\mathrm{c}$ & & & 2 & & \\
\hline Water depth & - & 0 & - & + & 0 & 0 & 0 & 0 & 0 & 0 & 0 & 0 & 0 & - & 0 & 0 & 0 & 0 & + & 0 & 0 & 0 & 0 & 0 \\
\hline Sediment thickness & 0 & 0 & 0 & 0 & 0 & 0 & 0 & 0 & 0 & 0 & 0 & 0 & 0 & + & - & 0 & 0 & 0 & 0 & 0 & 0 & + & 0 & \\
\hline Age & 0 & 0 & - & 0 & 0 & 0 & 0 & 0 & 0 & - & 0 & - & 0 & - & - & 0 & 0 & 0 & 0 & - & 0 & 0 & 0 & 0 \\
\hline Basement depth & 0 & 0 & 0 & 0 & 0 & 0 & 0 & 0 & 0 & 0 & 0 & 0 & 0 & - & 0 & - & 0 & 0 & - & - & 0 & - & 0 & 0 \\
\hline Sonic velocity & 0 & - & 0 & 0 & -- & - & + & 0 & + & ++ & ND & -- & --- & 0 & -- & + & - & 01 & ND & 0 & -1 & ND & 0 & -- \\
\hline Density & - & - & - & + & - & 0 & + & 0 & ++ & + & ND & - & $--N D$ & - & - & + & -- & -1 & ND & -1 & NDI & ND & + & 0 \\
\hline $\mathrm{SiO}_{2}$ & 0 & 0 & 0 & 0 & - & - & 0 & - & - & 0 & - & 0 & 00 & -- & -0 & 0 & -- & 0 & 0 & - & + & - & 0 & 0 \\
\hline $\mathrm{Al}_{2} \mathrm{C}$ & 0 & 0 & 0 & + & - & 0 & 0 & 0 & - & 0 & 0 & 0 & +0 & 0 & + & -- & 0 & 0 & - & 0 & + & 0 & 0 & 0 \\
\hline $\mathrm{TiO}_{2}$ & 0 & H & + & -- & -0 & 0 & 0 & 0 & ++ & 0 & 0 & ++ & +++ & 0 & + & 0 & ++ & + & + & + & + & + & + & + \\
\hline Total iron as $\mathrm{Fe}_{2} \mathrm{O}_{3}$ & 0 & 0 & 0 & - & ++ & 0 & 0 & 0 & ++ & 0 & + & 0 & $0+$ & 0 & 0 & + & 0 & 0 & 0 & 0 & - & 0 & 0 & + \\
\hline $\mathrm{MgO}$ & -- & -- & - & ++ & + & 0 & 0 & ++ & + & 0 & 0 & - & --0 & 0 & - & - & - & -- & 0 & & -- & 0 & - & 0 \\
\hline $\mathrm{CaC}$ & -- & -- & - & ++ & 0 & 0 & 0 & ++ & 0 & 0 & 0 & -- & - - - & 0 & - & 0 & - & -- & 0 & - & -- & - & 0 & - \\
\hline $\mathrm{Na}_{2} \mathrm{O}$ & + & ++ & + & -- & - & 0 & 0 & -- & - & 0 & - & 0 & ++++ & 0 & ++ & 0 & ++ & ++ & 0 & + & ++ & 0 & 0 & 0 \\
\hline $\mathrm{K}_{2} \mathrm{O}$ & ++ & ++ & ++ & 0 & + & + & 0 & 0 & 0 & 0 & ++ & 0 & $0+$ & + & 0 & 0 & 0 & 0 & 0 & + & & ++ & 0 & 0 \\
\hline $\mathrm{H}_{2} \mathrm{O}$ & 0 & 0 & 0 & 0 & + & + & 0 & 0 & 0 & 0 & + & 0 & $0+$ & + & 0 & 0 & 0 & 0 & 0 & + & -1 & ++ & 0 & 0 \\
\hline MnO & 0 & 0 & 0 & 0 & 0 & 0 & 0 & 0 & 0 & 0 & ND & 0 & $0+$ & 0 & 0 & 0 & 0 & 0 & 0 & 0 & & ++ & 0 & 0 \\
\hline $\mathrm{P}_{2} \mathrm{O}_{5}$ & + & ++ & ++ & - & - & - & 0 & - & -- & 0 & 0 & ++ & ++++ & + & + & 0 & ++ & ++ & 0 & ++ & ++ & 0 & + & 0 \\
\hline $\mathrm{Fe}_{2} \mathrm{O}_{3}$ & 0 & 0 & 0 & 0 & 0 & 0 & 0 & + & 0 & 0 & + & + & NDND & ++ & NDI & ND & 0 & 0 & 0 & + & 0 & 0 & 0 & 0 \\
\hline $\mathrm{FeC}$ & 0 & 0 & 0 & -- & 0 & 0 & 0 & 0 & + & 0 & 0 & - & NDND & - & $\mathrm{ND}$ & ND & 0 & - & 0 & - & -- & 0 & 0 & + \\
\hline $\mathrm{Fe}_{2} \mathrm{O}_{3} / \mathrm{FeO}$ & 0 & 0 & 0 & 0 & 0 & 0 & 0 & 0 & 0 & 0 & 0 & + & NDND & ++ & $\mathrm{ND}$ & ND & 0 & ++ & 0 & + & ++ & + & 0 & 0 \\
\hline
\end{tabular}


TABLE B3

All DSDP Data Correlation Matrix Trace Elements

\begin{tabular}{|c|c|c|c|c|c|c|c|c|c|c|c|c|c|c|c|c|c|c|c|c|c|c|c|c|c|}
\hline & $\mathrm{Ba}$ & $\mathrm{Sr}$ & $\mathrm{Zr}$ & $\mathrm{Cr}$ & Co & $\mathrm{Cu}$ & $\mathrm{Ga}$ & $\mathrm{Ni}$ & V & $\mathrm{Y}$ & B & $\mathrm{Cl}$ & Eu & Hf & $\mathrm{Li}$ & $\mathrm{Pb}$ & Mo & $\mathrm{Nb}$ & $\mathrm{Rb}$ & Sc & Th & $\mathrm{U}$ & $\mathrm{Yb}$ & $\mathrm{Zn}$ & $S$ \\
\hline $\mathrm{Ba}$ & & ++ & + & - & - & - & 0 & - & -- & 0 & 0 & ++ & ++ & + & + & ++ & 0 & + & ++ & 0 & ++ & + & 0 & 0 & 0 \\
\hline $\mathrm{Sr}$ & H & & ++ & 0 & 0 & 0 & 0 & 0 & - & 0 & 0 & ++ & ++ & ND & 0 & ND & ND & + & + & 0 & ++ & ++ & 0 & 0 & 0 \\
\hline $\mathrm{Zr}$ & + & ++ & & 0 & - & 0 & + & 0 & 0 & ++ & 0 & 0 & + & ++ & 0 & + & 0 & + & + & 0 & ++ & ++ & 0 & 0 & 0 \\
\hline $\mathrm{Cr}$ & - & 0 & 0 & & 0 & 0 & 0 & + & 0 & 0 & 0 & ND & ND & ND & 0 & ND & ND & 0 & 0 & -- & ND & ND & 0 & 0 & ND \\
\hline Co & - & 0 & - & 0 & & + & 0 & + & + & - & + & ND & ND & ND & ND & ND & ND & + & 0 & 0 & ND & - & 0 & + & ND \\
\hline $\mathrm{Cu}$ & - & 0 & 0 & 0 & 0 & & 0 & 0 & + & 0 & 0 & ND & ND & ND & 0 & ND & ND & + & 0 & 0 & ND & - & 0 & 0 & ND \\
\hline $\mathrm{Ga}$ & 0 & 0 & ++ & 0 & 0 & 0 & & 0 & 0 & + & 0 & ND & ND & ND & + & ND & ND & + & 0 & + & ND & + & ++ & 0 & ND \\
\hline $\mathrm{Ni}$ & - & 0 & 0 & + & + & 0 & 0 & & 0 & 0 & 0 & ND & ND & ND & + & ND & 0 & 0 & 0 & 0 & ND & - & 0 & 0 & ND \\
\hline V & -- & - & 0 & 0 & + & + & 0 & 0 & & 0 & + & ND & ND & ND & - & ND & 0 & 0 & 0 & + & ND & - & + & 0 & ND \\
\hline Y & 0 & 0 & ++ & 0 & - & 0 & + & 0 & 0 & & - & 0 & ND & ND & 0 & ND & ND & 0 & 0 & 0 & + & + & + & 0 & 0 \\
\hline B & 0 & 0 & 0 & 0 & + & 0 & 0 & 0 & + & - & & ND & ND & ND & ND & ND & ND & ND & ND & ND & ND & 0 & ND & ND & ND \\
\hline $\mathrm{Cl}$ & + & ++ & 0 & ND & ND & ND & ND & ND & ND & 0 & ND & & ND & ND & ND & ND & ND & + & + & ND & + & ND & ND & ND & 0 \\
\hline Eu & + & ++ & + & ND & ND & ND & ND & ND & ND & ND & ND & ND & & ++ & ND & + & + & ND & ND & ND & + & + & 0 & ND & 0 \\
\hline Hf & + & ND & + & ND & ND & ND & ND & ND & ND & ND & ND & ND & + & & ND & + & 0 & + & ND & ND & + & ND & ND & ND & + \\
\hline $\mathbf{L i}$ & + & 0 & 0 & 0 & ND & 0 & + & + & - & 0 & ND & ND & NI) & ND & & ND & ND & ND & + & ND & ND & ND & ND & 0 & ND \\
\hline $\mathrm{Pb}$ & + & ND & + & ND & ND & ND & ND & ND & ND & ND & ND & ND & + & + & ND & & 0 & + & ND & ND & + & + & ND & ND & 0 \\
\hline Mo & 0 & ND & 0 & ND & ND & ND & ND & 0 & 0 & ND & ND & ND & + & () & ND & () & & 0 & ND & ND & 0 & + & ND & ND & 0 \\
\hline $\mathrm{Nb}$ & + & ++ & ++ & 0 & + & + & + & 0 & 0 & 0 & ND & + & ND & + & ND & + & 0 & & ++ & ND & ++ & + & 0 & + & 0 \\
\hline $\mathrm{Rb}$ & ++ & + & + & 0 & 0 & 0 & 0 & 0 & 0 & 0 & ND & + & ND & ND & + & ND & ND & + & & ND & + & ND & ND & 0 & 0 \\
\hline Sc & 0 & 0 & 0 & -- & 0 & 0 & + & 0 & + & () & ND & ND & ND & ND & ND & ND & ND & ND & ND & & ND & ND & + & ND & ND \\
\hline Th & + & ++ & ++ & ND & ND & ND & ND & ND & ND & + & ND & + & + & + & ND & + & 0 & H & + & ND & & + & ND & ND & 0 \\
\hline U & + & + & ++ & ND & - & - & + & - & - & + & ND & ND & + & ND & ND & + & + & + & ND & ND & + & & ND & ND & 0 \\
\hline $\mathrm{Yb}$ & 0 & 0 & 0 & 0 & 0 & 0 & ++ & 0 & + & + & ND & ND & 0 & ND & ND & ND & ND & 0 & ND & + & ND & ND & & ND & ND \\
\hline $\mathrm{Zn}$ & 0 & 0 & 0 & 0 & + & 0 & 0 & 0 & 0 & 0 & ND & ND & ND & ND & 0 & ND & ND & + & 0 & ND & ND & ND & ND & & ND \\
\hline $\mathbf{S}$ & 0 & 0 & 0 & ND & ND & ND & ND & ND & ND & 0 & ND & 0 & 0 & + & ND & 0 & 0 & 0 & 0 & ND & 0 & 0 & ND & ND & \\
\hline
\end{tabular}

TABLE B4

Typical Ocean Profile Samples

Correlation Matrix Major Elements, Physical Properties, Site Characteristics

\begin{tabular}{|c|c|c|c|c|c|c|c|c|c|c|c|c|c|c|c|c|c|c|c|c|}
\hline & & 1 & 2 & 3 & 4 & 5 & 6 & 7 & 8 & 9 & 10 & & 12 & 13 & 141 & 15 & & & & 192 \\
\hline 1 & Water depth & & 0 & ++ & 0 & - & - & 0 & 0 & 0 & 0 & 0 & 0 & 0 & + & + & + & 0 & 0 & - \\
\hline 2 & Sediment thickness & 0 & & 0 & + & + & 0 & 0 & 0 & 0 & 0 & 0 & 0 & 0 & 0 & + & 0 & 0 & + & - \\
\hline 3 & Age & ++ & 0 & & + & 0 & 0 & 0 & 0 & 0 & 0 & 0 & 0 & 0 & 0 & 0 & + & 0 & 0 & 0 \\
\hline 4 & Basement depth & 0 & + & + & & + & ++ & + & 0 & - & 0 & + & 0 & - & - & 0 & 0 & - & -- & 0 \\
\hline 5 & Sonic & - & + & 0 & + & & ++ & 0 & 0 & -- & 0 & 0 & ++ & - & -- & -- & 0 . & -- & -- & ++ \\
\hline 6 & Density & - & 0 & 0 & ++ & ++ & & + & + & - & 0 & + & ++ & -- & -- & -- & 0 & -- & -- & 0 \\
\hline 7 & $\mathrm{SiO}_{2}$ & 0 & 0 & 0 & + & 0 & + & & 0 & 0 & 0 & 0 & 0 & 0 & 0 & - & 0 & 0 & -- & + \\
\hline 8 & $\mathrm{Al}_{2} \mathrm{O}_{3}$ & 0 & $\mathbf{0}$ & 0 & 0 & 0 & + & 0 & & - & -- & 0 & 0 & 0 & 0 & 0 & 0 & 0 & 0 & $--\left(\begin{array}{c}0 \\
-1\end{array}\right)$ \\
\hline 9 & $\mathrm{TiO}_{2}$ & 0 & 0 & 0 & - & -- & -- & 0 & - & & ++ & - & -- & ++ & + & 0 & 0 & ++ & & 0 \\
\hline 10 & Total iron as $\mathrm{Fe}_{2} \mathrm{O}_{3}$ & 0 & 0 & 0 & 0 & 0 & 0 & 0 & -- & ++ & & 0 & 0 & 0 & 0 & - & 0 & + & & ++ \\
\hline 11 & $\mathrm{MgO}$ & 0 & 0 & 0 & + & 0 & + & 0 & 0 & - & 0 & & 0 & - & - & 0 & 0 & & -- & 0 \\
\hline 12 & $\mathrm{CaO}$ & 0 & 0 & 0 & 0 & ++ & ++ & 0 & 0 . & -- & 0 & 0 & & - & -- & - & 0 & -- & 0 & 0 \\
\hline 13 & $\mathrm{Na}_{2} \mathrm{O}$ & 0 & 0 & 0 & - & - & -- & 0 & 0 & ++ & 0 & - & - & & + & 0 & 00 & ++ & + & 0 \\
\hline 14 & $\mathrm{~K}_{2} \mathrm{O}$ & + & 0 & 0 & - & -- & - & 0 & 0 & + & 0 & - & -- & + & & ++ & 0 & + & + & -+ \\
\hline 15 & $\mathrm{H}_{2} \mathrm{O}$ & + & + & 0 & 0 & -- & - & -- & 0 & 0 & - & 0 & -- & 0 & ++ & & 0 & 0 . & ++ & --+ \\
\hline 16 & $\mathrm{MnO}$ & + & 0 & + & 0 & 0 & 0 & 0 & 0 & 0 & 0 & 0 & 0 & 0 & & 0 & & 0 & + & -- \\
\hline 17 & $\mathrm{P}_{2} \mathrm{O}_{5}$ & 0 & 0 & 0 & - & -- & - & 0 & 0 & ++ & + & - & -- & ++ & + & 0 & 0 & & & 0 \\
\hline 18 & $\mathrm{Fe}_{2} \mathrm{O}_{3}$ & 0 & + & 0 & -- & -- & -- & -- & 0 & 0 & 0 & -- & 0 & + & ++ & ++ & + & + & & --+ \\
\hline 19 & $\mathrm{FeO}$ & - & - & 0 & 0 & ++ & 0 & + & -- & 0 & ++ & 0 & 0 & 0 & - & & -- & 0 . & -- & \\
\hline 20 & $\mathrm{Fe}_{2} \mathrm{O}_{3} / \mathrm{FeO}$ & 0 & + & 0 & - & -- & - & - & 0 & 0 & 0 & & -- & 0 & +++ & ++ & + & + & ++ & -- \\
\hline
\end{tabular}


TABLE B5

Typical Ocean Profile Samples Correlation Matrix Major Properties Versus Trace Elements

Ba Sr Zr Cr Co Cu Ga Ni V Y B Cl Eu Hf Li Pb Mo Nb Rb Sc Th U Yb Zn S

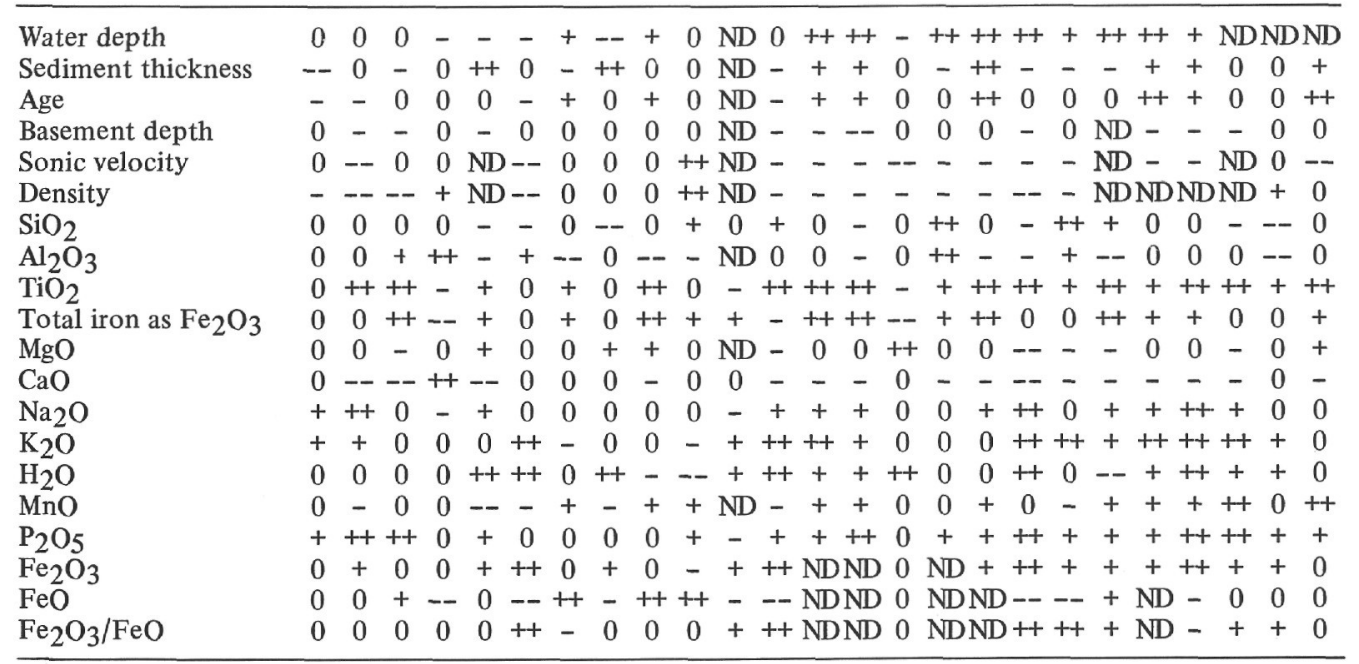

TABLE B6

Typical Ocean Profile Samples: Correlation Matrix Trace Elements

\begin{tabular}{|c|c|c|c|c|c|c|c|c|c|c|c|c|c|c|c|c|c|c|c|c|c|c|c|c|c|}
\hline & $\mathrm{Ba}$ & $\mathrm{Sr}$ & $\mathrm{Zr}$ & $\mathrm{Cr}$ & $\mathrm{Co}$ & $\mathrm{Cu}$ & $\mathrm{Ga}$ & $\mathrm{Ni}$ & V & $\mathrm{Y}$ & B & $\mathrm{Cl}$ & $\mathrm{Eu}$ & Hf & $\mathrm{Li}$ & $\mathrm{Pb}$ & Mo & $\mathrm{Nb}$ & $\mathbf{R b}$ & $\mathrm{Si}$ & Th & $\mathbf{U}$ & $\mathrm{Yb}$ & $\mathrm{Zn}$ & $\mathbf{S}$ \\
\hline $\mathrm{Ba}$ & & ++ & 0 & 0 & 0 & 0 & 0 & 0 & 0 & 0 & ND & ND & ++ & ++ & 0 & 0 & ++ & ++ & ++ & + & + & 0 & + & 0 & 0 \\
\hline $\mathrm{Sr}$ & ++ & & + & 0 & ++ & 0 & 0 & 0 & 0 & 0 & - & + & ND & ND & 0 & ND & ND & ++ & + & 0 & ND & + & + & + & + \\
\hline $\mathrm{Zr}$ & 0 & + & & - & 0 & - & + & - & ++ & ++ & - & + & ND & ++ & - & + & 0 & ++ & 0 & + & + & ++ & + & 0 & + \\
\hline $\mathrm{Cr}$ & 0 & 0 & - & & 0 & 0 & - & + & -- & - & - & ND & ND & ND & 0 & ND & ND & ND & - & - & ND & 0 & - & 0 & ND \\
\hline Co & 0 & ++ & 0 & 0 & & - & + & ++ & 0 & 0 & 0 & ND & ND & ND & ND & ND & ND & ND & ND & 0 & ND & ND & ND & ND & ND \\
\hline $\mathrm{Cu}$ & 0 & 0 & - & 0 & - & & -- & 0 & - & - & + & ND & ND & ND & + & ND & ND & ND & ND & 0 & ND & ND & + & 0 & ND \\
\hline $\mathrm{Ga}$ & 0 & 0 & + & - & + & -- & & 0 & ++ & 0 & 0 & ND & ND & ND & - & ND & ND & ND & - & + & ND & ND & ND & 0 & ND \\
\hline $\mathrm{Ni}$ & 0 & 0 & - & + & ++ & 0 & 0 & & 0 & 0 & - & ND & ND & ND & ++ & ND & ND & ND & - & - & ND & ND & ND & 0 & ND \\
\hline V & 0 & 0 & ++ & -- & 0 & - & ++ & 0 & & + & + & ND & ND & ND & - & ND & ND & ND & - & + & ND & ND & ND & 0 & ND \\
\hline Y & 0 & 0 & ++ & - & 0 & - & 0 & 0 & + & & - & -- & ND & ND & - & ND & ND & -- & - & + & ND & + & ++ & 0 & 0 \\
\hline B & ND & - & - & - & 0 & + & 0 & - & + & - & & ND & ND & ND & ND & ND & ND & ND & ND & ND & ND & ND & ND & ND & ND \\
\hline $\mathrm{Cl}$ & ND & + & + & ND & ND & ND & ND & ND & ND & -- & ND & & ND & ND & ND & ND & ND & ++ & ++ & ND & ND & + & ND & ND & 0 \\
\hline $\mathrm{Eu}$ & ++ & ND & ND & ND & ND & ND & ND & ND & ND & ND & ND & ND & & ND & ND & + & ++ & ++ & ND & ND & + & + & ND & ND & ++ \\
\hline Hf & ++ & ND & ++ & ND & ND & ND & ND & ND & ND & ND & ND & ND & ND & & ND & + & ++ & ++ & ND & ND & ND & ND & ND & ND & ++ \\
\hline $\mathrm{Li}$ & 0 & 0 & - & 0 & ND & + & - & ++ & - & - & ND & ND & ND & ND & & ND & ND & ND & ND & ND & ND & ND & ND & ND & ND \\
\hline $\mathrm{Pb}$ & 0 & ND & + & ND & ND & ND & ND & ND & ND & ND & ND & ND & + & + & ND & & 0 & 0 & ND & 0 & ND & 0 & ND & ND & + \\
\hline Mo & ++ & ND & 0 & ND & ND & ND & ND & ND & ND & ND & ND & ND & ++ & ++ & ND & 0 & & ++ & ND & ND & ND & + & ND & ND & + \\
\hline $\mathrm{Nb}$ & ++ & ++ & ++ & ND & ND & ND & ND & ND & ND & -- & ND & ++ & ++ & ++ & ND & 0 & ++ & & ++ & ND & + & ++ & ND & ND & 0 \\
\hline$R b$ & ++ & + & 0 & - & ND & ND & - & - & - & - & ND & ++ & ND & ND & ND & ND & ND & ++ & & ND & ND & ND & ND & - & 0 \\
\hline $\mathrm{Si}$ & + & 0 & + & - & 0 & 0 & + & - & + & + & ND & ND & ND & ND & ND & 0 & ND & ND & ND & & ND & ND & + & ND & ND \\
\hline Th & + & ND & + & ND & ND & ND & ND & ND & ND & ND & ND & ND & + & ND & ND & ND & ND & + & ND & ND & & + & ND & ND & + \\
\hline U & 0 & + & ++ & 0 & ND & ND & ND & ND & MD & + & ND & + & + & ND & ND & 0 & + & ++ & ND & ND & + & & ND & ND & + \\
\hline $\mathrm{Yb}$ & + & + & + & - & ND & + & ND & ND & ND & ++ & ND & ND & ND & ND & ND & ND & ND & ND & ND & + & ND & ND & & ND & ND \\
\hline $\mathrm{Zn}$ & 0 & + & 0 & 0 & ND & 0 & 0 & 0 & 0 & 0 & ND & ND & ND & ND & ND & ND & ND & ND & - & ND & ND & ND & ND & & ND \\
\hline S & + & + & + & ND & ND & ND & ND & ND & ND & 0 & ND & 0 & ++ & ++ & ND & + & + & 0 & 0 & ND & + & + & ND & ND & \\
\hline
\end{tabular}

TABLE B7

Ridge Basalt Correlation Matrix: Major Elements

\begin{tabular}{|c|c|c|c|c|c|c|c|c|c|c|c|c|c|c|c|c|}
\hline & & 1 & 2 & 3 & 4 & 5 & 6 & 7 & 8 & 9 & & 11 & 12 & 13 & 14 & 15 \\
\hline 1 & & & + & - & 0 & 0 & 0 & - & 0 & - & 0 & 0 & 0 & 0 & - & 0 \\
\hline 2 & $\mathrm{SiO}_{2}$ & + & & 0 & 0 & 0 & 0 & 0 & + & 0 & 0 & 0 & 0 & - & 0 & - \\
\hline 3 & $\mathrm{Al}_{2} \mathrm{O}_{3}$ & - & 0 & & -- & -- & - & ++ & 0 & 0 & 0 & - & - & 0 & -- & 0 \\
\hline 4 & $\mathrm{TiO}_{2}$ & 0 & 0 & -- & & ++ & 0 & -- & 0 & 0 & 0 & ++ & + & + & ++ & 0 \\
\hline 5 & Total iron as $\mathrm{Fe}_{2} \mathrm{O}_{3}$ & 0 & 0 & -- & ++ & & 0 & - & 0 & 0 & 0 & + & ++ & 0 & ++ & 0 \\
\hline 6 & $\mathrm{MgO}$ & 0 & 0 & - & 0 & 0 & & 0 & 0 & 0 & 0 & 0 & - & 0 & 0 & - \\
\hline 7 & $\mathrm{CaO}$ & - & 0 & + & - & -- & 0 & & - & 0 & 0 & 0 & - & - & 0 & - \\
\hline 8 & $\mathrm{NaO}$ & 0 & + & 0 & 0 & 0 & 0 & - & & 0 & 0 & 0 & 0 & 0 & 0 & 0 \\
\hline 9 & $\mathrm{~K}_{2} \mathrm{O}$ & - & 0 & 0 & 0 & 0 & 0 & 0 & 0 & & 0 & 0 & 0 & 0 & 0 & 0 \\
\hline 10 & $\mathrm{H}_{2} \mathrm{O}$ & 0 & 0 & 0 & 0 & 0 & 0 & 0 & 0 & 0 & & 0 & 0 & + & 0 & + \\
\hline 11 & $\mathrm{MnO}$ & 0 & 0 & - & ++ & + & 0 & 0 & 0 & 0 & 0 & & + & 0 & + & 0 \\
\hline 12 & $\mathrm{P}_{2} \mathrm{O}_{5}$ & 0 & 0 & - & ++ & ++ & - & - & 0 & 0 & 0 & + & & 0 & + & 0 \\
\hline 13 & $\mathrm{Fe}_{2} \mathrm{O}_{3}$ & 0 & - & 0 & + & 0 & 0 & - & 0 & 0 & + & 0 & 0 & & 0 & ++ \\
\hline 14 & $\mathrm{FeO}$ & + & 0 & -- & ++ & ++ & 0 & 0 & 0 & 0 & 0 & + & + & 0 & & - \\
\hline 15 & $\mathrm{Fe}_{2} \mathrm{O}_{3} / \mathrm{FeO}$ & 0 & - & 0 & 0 & 0 & - & -- & 0 & 0 & + & $u$ & 0 & ++ & - & \\
\hline
\end{tabular}


TABLE B8

Ridge Basalt Correlation Matrix: Major Elements Versus Trace Elements

\begin{tabular}{|c|c|c|c|c|c|c|c|c|c|c|c|c|c|c|c|c|c|c|c|c|c|c|c|c|c|}
\hline & $\mathrm{Ba}$ & $\mathrm{Sr}$ & $\mathrm{Zr}$ & $\mathrm{Cr}$ & Co & $\mathrm{Cu}$ & $\mathrm{Ga}$ & $\mathrm{Ni}$ & V & $\mathrm{Y}$ & B & $\mathrm{Cl}$ & $\mathrm{Eu}$ & $\mathrm{Hf}$ & $\mathrm{Li}$ & $\mathrm{Pb}$ & Mo & $\mathrm{Nb}$ & $\mathrm{Rb}$ & $\mathrm{Sc}$ & Th & $\mathrm{U}$ & $\mathrm{Yb}$ & $\mathrm{Zn}$ & $S$ \\
\hline Water depth & 0 & 0 & + & -- & + & + & 0 & + & 0 & ++ & ND & ND & - & ND & ++ & + & ND & ND & -- & -- & ND & ND & 0 & + & ND \\
\hline $\mathrm{SiO}_{2}$ & + & 0 & 0 & -- & 0 & ++ & ++ & 0 & ++ & + & ND & ND & - & ND & 0 & - & ND & ND & 0 & 0 & ND & ND & 0 & 0 & ND \\
\hline $\mathrm{Al}_{2} \mathrm{O}_{3}$ & - & 0 & -- & + & -- & - & - & 0 & -- & -- & ND & 0 & - & ND & - & ++ & ND & - & 0 & -- & ND & ND & -- & -- & ND \\
\hline $\mathrm{TiO}_{3}$ & 0 & 0 & ++ & 0 & 0 & 0 & 0 & 0 & 0 & ++ & ND & ND & + & ND & + & ++ & ND & 0 & 0 & 0 & ND & ND & ++ & ++ & ND \\
\hline Total iron as $\mathrm{Fe}_{2} \mathrm{O}_{3}$ & 0 & 0 & ++ & 0 & 0 & 0 & + & 0 & ++ & ++ & ND & 0 & + & 0 & + & - & ND & ND & 0 & ++ & ND & ND & ++ & ++ & ND \\
\hline $\mathrm{MaO}$ & ++ & - & 0 & 0 & + & 0 & ++ & +t & + & + & ND & ND & 0 & ND & 0 & -- & ND & ND & + & + & & ND & 0 & 0 & ND \\
\hline \multirow[t]{2}{*}{$\mathrm{CaO}$} & 0 & 0 & -- & 0 & - & 0 & 0 & 0 & - & -- & ND & ND & 0 & ND & - & 0 & ND & 0 & 0 & - & ND & ND & -- & -- & ND \\
\hline & 0 & + & ++ & 0 & 0 & 0 & 0 & 0 & 0 & ++ & ND & ND & - & ND & ++ & 0 & ND & ND & 0 & 0 & ND & ND & + & + & ND \\
\hline $\mathrm{K}_{2} \mathrm{O}$ & ++ & 0 & + & 0 & ++ & + & ++ & + & ++ & ++ & ND & 0 & 0 & ND & ++ & - & ND & 0 & ++ & 0 & ND & ND & + & + & ND \\
\hline $\mathrm{H}_{2} \mathrm{O}$ & -- & + & 0 & 0 & 0 & 0 & - & - & - & + & ND & ND & + & ND & + & ++ & ND & 0 & ++ & 0 & ND & ND & + & + & ND \\
\hline $\mathrm{MnO}$ & -- & 0 & + & 0 & 0 & 0 & - & 0 & 0 & ++ & ND & ND & ND & ND & 0 & + & ND & ND & - & 0 & ND & ND & + & + & ND \\
\hline $\mathrm{P}_{2} \mathrm{O}_{5}$ & 0 & + & ++ & 0 & 0 & 0 & 0 & -- & 0 & ++ & ND & ND & ND & ND & 0 & ND & ND & ND & - & 0 & ND & ND & ++ & + & ND \\
\hline $\mathrm{Fe}_{2} \mathrm{O}_{3}$ & -- & + & + & 0 & 0 & 0 & 0 & - & - & 0 & ND & ND & ND & ND & ++ & ++ & ND & 0 & ND & 0 & ND & ND & ++ & + & ND \\
\hline $\mathrm{FeO}$ & + & 0 & ++ & 0 & + & 0 & + & 0 & ++ & ++ & ND & ND & ND & ND & + & -- & ND & ND & ND & ++ & ND & ND & ++ & ++ & ND \\
\hline $\mathrm{Fe}_{2} \mathrm{O}_{3} / \mathrm{FeO}$ & -- & ++ & 0 & 0 & 0 & - & - & -- & -- & 0 & ND & ND & ND & ND & + & ++ & ND & ND & ND & - & ND & ND & 0 & 0 & ND \\
\hline
\end{tabular}

TABLE B9

Ridge Basalt Correlation Matrix: Trace Elements

\begin{tabular}{|c|c|c|c|c|c|c|c|c|c|c|c|c|c|c|c|c|c|c|c|c|c|c|c|c|c|}
\hline & $\mathrm{Ba}$ & $\mathrm{Sr}$ & $\mathrm{Zr}$ & $\mathrm{Cr}$ & Co & $\mathrm{Cu}$ & $\mathrm{Ga}$ & $\mathrm{Ni}$ & V & Y & B & $\mathrm{Cl}$ & $\mathrm{Eu}$ & $\mathrm{Hf}$ & $\mathrm{Li}$ & $\mathrm{Pb}$ & Mo & $\mathrm{Nb}$ & $\mathrm{Rb}$ & $\mathrm{Sc}$ & Th & $\mathrm{U}$ & $\mathrm{Yb}$ & $\mathrm{Zn}$ & $S$ \\
\hline $\mathrm{Ba}$ & & - & 0 & 0 & 0 & 0 & ++ & ++ & ++ & 0 & ND & ND & ND & ND & - & - & ND & ND & ++ & ++ & ND & ND & 0 & 0 & ND \\
\hline $\mathrm{Sr}$ & - & & 0 & - & - & 0 & 0 & 0 & + & ++ & ND & ND & ND & ND & 0 & + & ND & ND & 0 & 0 & ND & ND & 0 & 0 & ND \\
\hline $\mathrm{Zr}$ & 0 & 0 & & - & + & 0 & 0 & 0 & + & ++ & ND & ND & ND & ND & ++ & 0 & ND & ND & 0 & ++ & ND & ND & ++ & ++ & ND \\
\hline $\mathrm{Cr}$ & 0 & - & - & & 0 & - & 0 & 0 & - & - & ND & ND & ND & ND & -- & 0 & ND & + & + & - & ND & ND & -- & 0 & ND \\
\hline Co & 0 & - & + & 0 & & + & + & ++ & 0 & 0 & ND & ND & ND & ND & ++ & ++ & ND & ND & ND & ++ & ND & ND & ++ & + & ND \\
\hline $\mathrm{Cu}$ & 0 & 0 & 0 & - & + & & ++ & + & 0 & + & ND & ND & ND & ND & ++ & ++ & ND & + & ND & ++ & ND & ND & ++ & + & ND \\
\hline $\mathrm{Ga}$ & ++ & 0 & 0 & 0 & + & ++ & & ++ & ++ & ++ & ND & ND & ND & ND & ++ & - & ND & ND & + & + & ND & ND & + & 0 & ND \\
\hline $\mathrm{Ni}$ & ++ & 0 & 0 & 0 & ++ & + & ++ & & + & - & ND & ND & - & ND & 0 & -- & ND & + & 0 & ++ & ND & ND & - & - & ND \\
\hline V & ++ & + & + & - & 0 & 0 & ++ & + & & ++ & ND & ND & ND & ND & 0 & -- & ND & ND & ND & ++ & ND & ND & ++ & + & ND \\
\hline Y & 0 & ++ & ++ & - & 0 & + & ++ & - & ++ & & ND & ND & ND & ND & ++ & ND & ND & ND & ND & ++ & ND & ND & ++ & ++ & ND \\
\hline B & ND & ND & ND & ND & ND & ND & ND & ND & ND & ND & & ND & ND & ND & ND & ND & ND & ND & ND & ND & ND & ND & ND & ND & ND \\
\hline $\mathrm{Cl}$ & ND & ND & ND & ND & ND & ND & ND & ND & ND & ND & ND & & ND & ND & ND & ND & ND & ND & ND & ND & ND & ND & ND & ND & ND \\
\hline $\mathrm{Eu}$ & ND & ND & ND & ND & ND & ND & ND & ND & ND & ND & ND & ND & & ND & ND & ND & ND & ND & ND & ND & ND & ND & ++ & ND & ND \\
\hline $\mathrm{Hf}$ & ND & ND & ND & ND & ND & ND & ND & ND & ND & ND & ND & ND & ND & & ND & ND & ND & ND & ND & ND & ND & ND & ND & ND & ND \\
\hline $\mathrm{Li}$ & - & 0 & ++ & -- & ++ & ++ & ++ & 0 & 0 & ++ & ND & ND & ND & ND & & ND & ND & ND & ND & ND & ND & ND & + & ++ & ND \\
\hline $\mathrm{Pb}$ & - & + & 0 & 0 & ++ & ++ & - & -- & -- & ND & ND & ND & ND & ND & ND & & ND & ND & ND & - & ND & ND & ND & ++ & ND \\
\hline Mo & ND & ND & ND & ND & ND & ND & ND & ND & ND & ND & ND & ND & ND & ND & ND & ND & & ND & ND & ND & ND & ND & ND & ND & ND \\
\hline $\mathrm{Nb}$ & ND & ND & 0 & + & ND & + & ND & + & ND & ND & ND & ND & ND & ND & ND & ND & ND & & ND & ND & ND & ND & ND & ND & ND \\
\hline $\mathrm{Rb}$ & ++ & 0 & 0 & + & ND & ND & + & 0 & ND & ND & ND & ND & ND & ND & ND & ND & ND & ND & & ND & ND & ND & 0 & ND & ND \\
\hline $\mathrm{Sc}$ & ++ & 0 & ++ & - & ++ & ++ & + & ++ & ++ & ++ & ++ & ND & ND & ND & ND & 0 & ND & ND & ND & & ND & ND & 0 & + & ND \\
\hline Th & ND & ND & ND & ND & ND & ND & ND & ND & ND & ND & ND & ND & ND & ND & ND & ND & ND & ND & ND & ND & & ND & ND & ND & ND \\
\hline $\mathrm{U}$ & ND & ND & ND & ND & ND & ND & ND & ND & ND & ND & ND & ND & ND & ND & ND & ND & ND & ND & ND & ND & ND & & ND & ND & ND \\
\hline $\mathrm{Yb}$ & 0 & 0 & ++ & -- & ++ & ++ & ++ & - & ++ & ++ & ND & ND & ++ & ND & + & ND & ND & ND & 0 & 0 & ND & ND & & ++ & ND \\
\hline $\mathrm{Zn}$ & 0 & 0 & ++ & 0 & + & + & 0 & - & + & ++ & ND & ND & ND & ND & ++ & ++ & ND & ND & ND & + & ND & ND & ++ & & ND \\
\hline $\mathrm{S}$ & ND & ND & ND & ND & ND & ND & ND & ND & ND & ND & ND & ND & ND & ND & ND & ND & ND & ND & ND & ND & ND & ND & ND & ND & \\
\hline
\end{tabular}

